Florida International University FIU Digital Commons

$11-8-2011$

\title{
The Relationship Between Staff Perceptions of Principal Leadership and School Performance
}

Andrea Floyd

Florida International University, Andrea630@aol.com

DOI: $10.25148 /$ etd.FI11120606

Follow this and additional works at: https://digitalcommons.fiu.edu/etd

\section{Recommended Citation}

Floyd, Andrea, "The Relationship Between Staff Perceptions of Principal Leadership and School Performance" (2011). FIU Electronic Theses and Dissertations. 500.

https://digitalcommons.fiu.edu/etd/500

This work is brought to you for free and open access by the University Graduate School at FIU Digital Commons. It has been accepted for inclusion in FIU Electronic Theses and Dissertations by an authorized administrator of FIU Digital Commons. For more information, please contact dcc@fiu.edu. 
FLORIDA INTERNATIONAL UNIVERSITY

Miami, Florida

THE RELATIONSHIP BETWEEN STAFF PERCEPTIONS OF

PRINCIPAL LEADERSHIP AND SCHOOL PERFORMANCE

A dissertation submitted in partial fulfillment of the

requirements for the degree of

DOCTOR OF EDUCATION

in

LEADERSHIP AND PROFESSIONAL STUDIES

by

Andrea Floyd

2011 
To: Dean Delia C. Garcia

College of Education

This dissertation, written by Andrea Floyd, and entitled The Relationship Between Staff Perceptions of Principal Leadership and School Performance, having been approved in respect to style and intellectual content, is referred to you for judgment.

We have read this dissertation and recommend that it be approved.

$\begin{array}{r}\hline \text { Roger Gonzalez } \\ \hline \text { Hilary Landorf } \\ \hline \text { Joan Wynne } \\ \hline \text { Peter J. Cistone, Major Professor }\end{array}$

Date of Defense: November 8, 2011

The dissertation of Andrea Floyd is approved.

Dean Delia C. Garcia

College of Education

Dean Lakshmi N. Reddi University Graduate School

Florida International University, 2011 


\section{DEDICATION}

One of the rare, beautiful experiences when completing a dissertation is this opportunity, the chance to publically dedicate your work to a small group of important individuals. This is a humbling, significant moment.

I dedicate this dissertation to my grandfather, Nicholas Izzo, and to David Priest. They are two men who won't physically see me graduate, but never doubted that I would. While it will not be obvious to most in the audience, I know they will both be walking across the stage with me as I become a doctor.

To my mother, Suzanne Floyd, thank you for instilling in me the importance of hard work and higher education, no matter the obstacles or barriers, and for counseling me to always look for the silver lining as menacing storm clouds approach. There is no better, more committed, "Stick with it!" speech-giver than you. I walk across the stage for you, Mom, serving as a tribute to your sacrifice and your devotion to our family.

To my father, Kenneth Floyd, thank you for modeling a life that is committed to the values you and Mom taught me at a young age. You are the epitome of kindness and compassion. Despite the miles that separate us physically, I carry you in my heart at all times.

To my steadfast sister, Jennie Floyd Webster (JBW), you have been selflessly loving and supportive beyond my wildest hopes. You are an inspiring daughter, sister, wife, mother and friend. Proverbs 31:10 asks, “A woman of valor, who can find?” I know your spirit, Jennie, and you are worth far more than rubies.

To my husband, Sean Beck, I am amazed every single day by your enduring hope and positivism. Deep in my heart, I know I am blessed to have a counterpart who brings 
strength to my weaknesses. Your youthful spirit and your unparalleled patience are gifts that I hope will be instilled in me with time and eventually passed down to our children. Thank you for loving me.

To Richard Webster, the older brother I was always searching for and lucky enough to find. Thank you for being a friend to me and a wonderful addition to our family. You have been my personal Rock of Gibraltar, and I would not be the woman I am today without you.

Finally, for my future children, for the light of all of our lives, Rebecca, and for my future niece or nephew, may the completion of this dissertation serve as an example of the vast divide between potential and achievement, and may it also serve as a testament to the belief that through hard work and perseverance, they, too, can aspire to achieve their heart's dreams. 


\section{ACKNOWLEDGMENTS}

As I complete this doctoral journey, I know that the only reason I have accomplished this dream is because other people have supported me in so many different ways. No undertaking of this magnitude is completed in isolation.

I want to express my sincere gratitude to my Major Professor, Dr. Peter J.

Cistone. You helped me stay even-keeled and focused, and encouraged me to never lose sight of my personal finish line. Your counsel, expertise, and time were invaluable throughout this process. In my eyes, you are Moses and Florida International University is your mountaintop.

I must also thank all of the members of my dissertation committee, Dr. Roger Gonzalez, Dr. Hilary Landorf and Dr. Joan Wynne. Your generous support and helpful suggestions contributed significantly to the quality of this finished product.

I would be remiss if I did not publicly thank Dr. Linda Bliss and Dr. Isadore Newman. The quality of this dissertation increased exponentially because of your efforts. I am appreciative of your time and expertise, and I am humbled by your supportive demonstration of how much I have yet to learn. There is no argument that you are both examples of the importance of life-long learning.

This dissertation would not exist if it were not for the contributions of Dr. Paulette Johnson and Holli Thometz in Florida International University's Statistical Consulting Department. You both speak a beautiful and exact language, statistics, that is foreign to me. Thank you for being patient with me.

Finally, and most deservedly, thank you to Caprila Almeida. Through the dissertation process, you consistently helped me to move forward and you provided an 
incredible source of support and assistance when I needed it most. You always had time, and a laugh, for me, and for that I am eternally grateful. Were it not for you, Caprila, I am certain this work would have never reached its full potential. 


\title{
ABSTRACT OF THE DISSERTATION \\ THE RELATIONSHIP BETWEEN STAFF PERCEPTIONS OF PRINCIPAL LEADERSHIP AND SCHOOL PERFORMANCE
}

\author{
by \\ Andrea Floyd \\ Florida International University, 2011 \\ Miami, Florida \\ Professor Peter J. Cistone, Major Professor
}

The climate of a school can be defined as the set of internal characteristics that distinguishes one school from another and influences the behavior of its members (Hoy \& Hannum, 1997). Schools with a positive climate have been shown to positively impact students (Hoy, 1972). A principal's leadership style influences the climate that, in turn, impacts student performance.

In this work, the researcher investigated Miami-Dade County Public Schools in order to determine if there was a relationship between instructional staff members' perceptions of their school's principals, a derivative of the district's school climate studies, and their schools' grades.

Eight School Climate Survey items were inter-correlated. The smallest intercorrelation was .83, which is still a large intercorrelation, and the largest intercorrelation was .96. Pearson's correlation analysis (Healey, 2004) was run to determine the relationship between schools' earned points and averaged survey responses. Survey items 8, 9, 12 and 13 had weak (less than .30) positive correlations to schools' earned points. Survey items 7, 10, 11 and 14 had moderate (above .30) positive correlations to schools' earned points.

The researcher created a composite variable (Pallant, 2007) from all the School Climate Survey responses. This composite variable, titled Principal Leadership Score, allowed the 
researcher to determine that approximately $9 \%$ of the variance in the points earned by schools in 2009 can be accounted for by how teachers in this study perceived the leadership of their principals.

This study's findings of a moderate positive correlation between teachers' perceptions of principal leadership and school performance supports earlier research linking school climate and school performance. Due to the fact that the leadership of the principal affects, either positively or negatively, the learning and working environment of students and teachers, it is recommended that principals use the eight School Climate Survey items examined within this study as guides (Pepper \& Thomas, 2002). Through focusing on these survey items, principals may be propelled to self-identify their leadership strengths as well as leadership weaknesses. 


\section{TABLE OF CONTENTS}

CHAPTER

PAGE

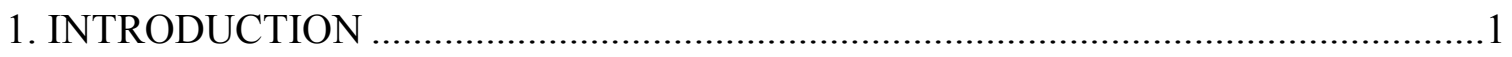

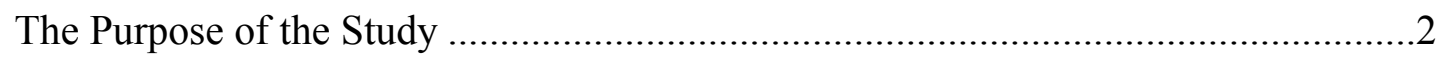

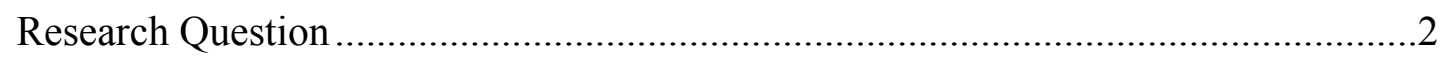

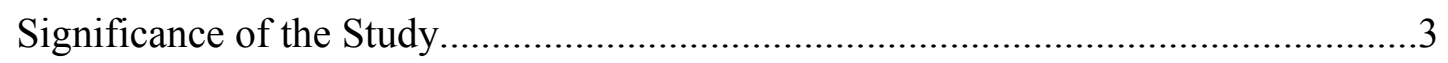

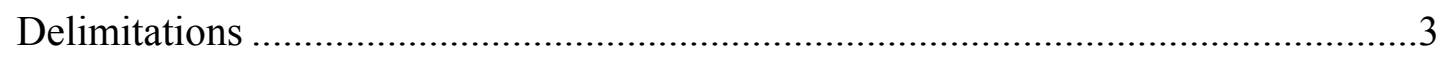

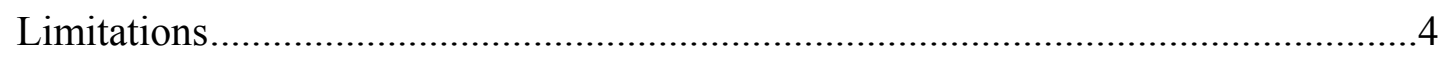

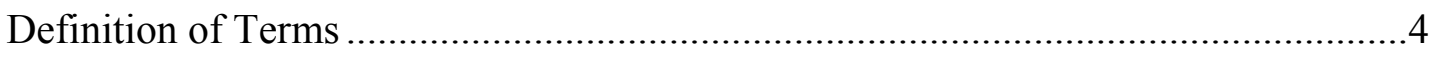

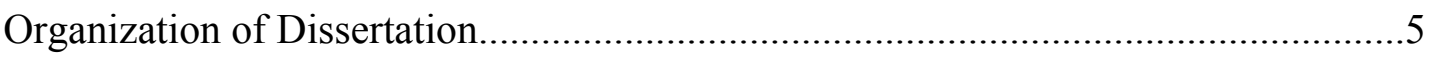

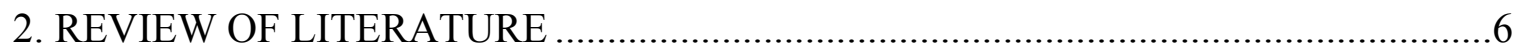

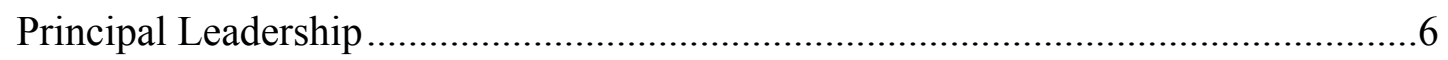

Impact of Principal Leadership on Student Performance.........................................11

Impact of School Climate on Student Performance ................................................ 13

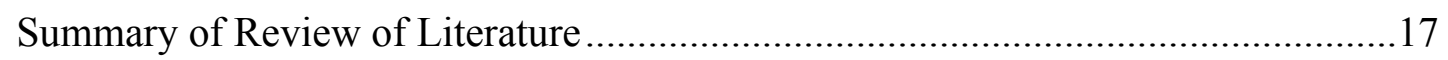

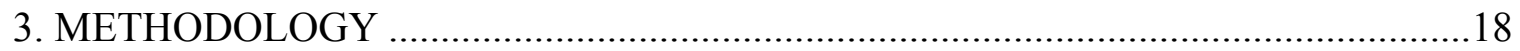

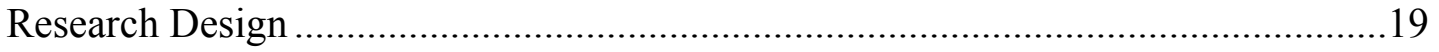

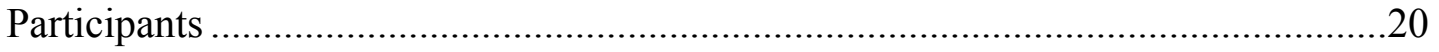

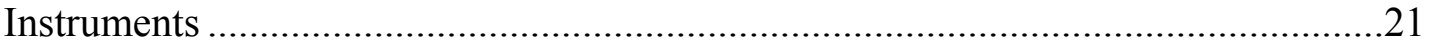

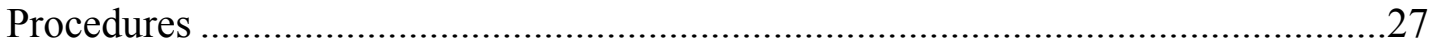

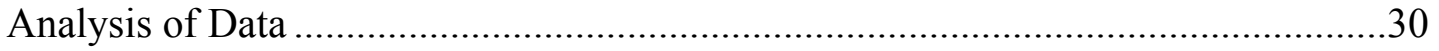

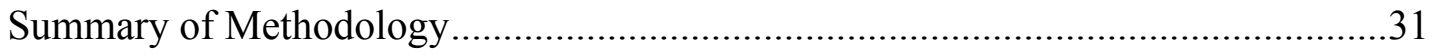

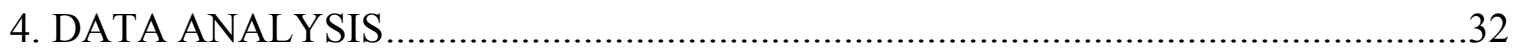

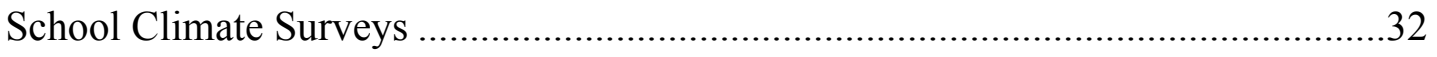

Correlation Between Points Earned and School Climate Survey Items ................... 37

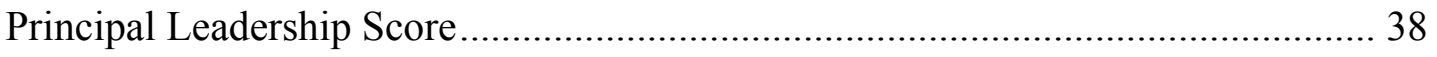

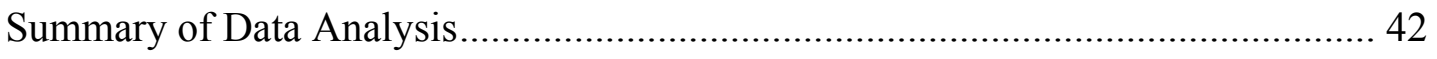


5. SUMMARY, IMPLICATIONS AND RECOMMENDATIONS

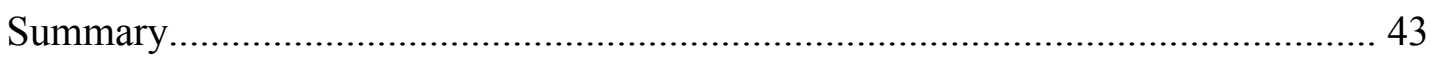

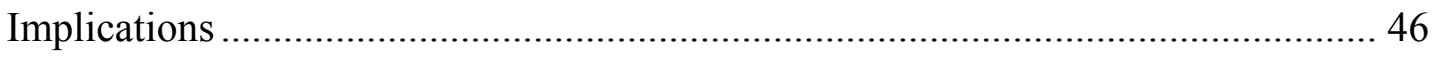

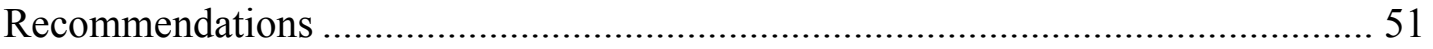

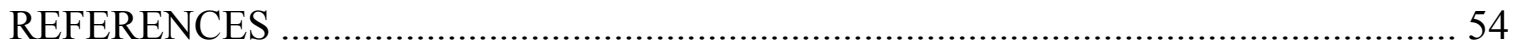

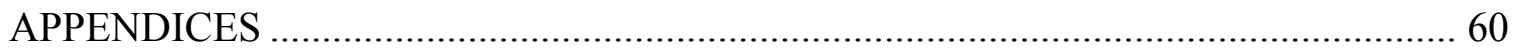

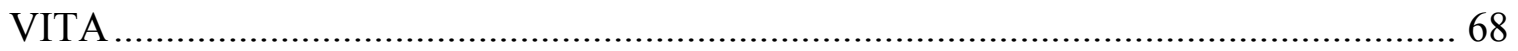




\section{LIST OF TABLES}

TABLE

PAGE

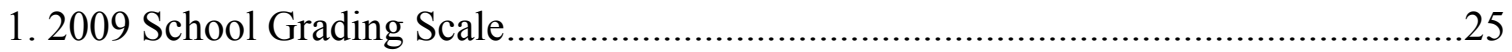

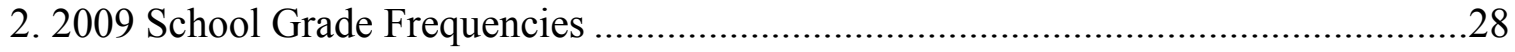

3. Distribution of Mean Percentage of Teachers and Standard Deviations for Item 7 .....33

4. Distribution of Mean Percentage of Teachers and Standard Deviations for Item 9 .....34

5. Distribution of Mean Percentage of Teachers and Standard Deviations for Item 12 ...34

6. Distribution of Mean Percentage of Teachers and Standard Deviations for Item 13 ...35

7. Distribution of Mean Percentage of Teachers and Standard Deviations for Each...

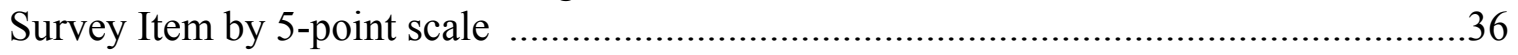

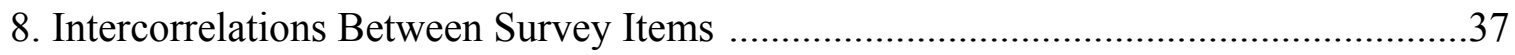

9. Correlations Between Points Earned and Survey Items ...........................................38

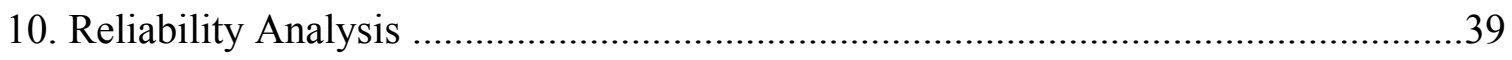

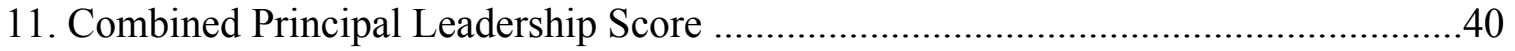

12. Mean Principal Leadership Score by Grade ..................................................... 40

13. Pearson's r Correlation Between Principal Leadership Score and Points Earned ......41

14. Distribution of Mean Percentage of Teachers and Standard Deviations for Each ...

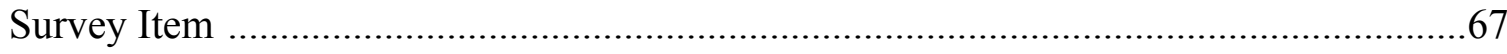




\section{CHAPTER I}

\section{INTRODUCTION}

Upon entering a school, students, visitors, and those who work within the institution immediately experience the climate of the organization. The term climate is a broad concept that refers to the individual perceptions of the school's work environment (Hoy \& Forsyth, 1986). The climate of a school can be defined as the set of internal characteristics that distinguishes one school from another and influences the behavior of its members (Hoy \& Hannum, 1997).

Hoy and Hannum (1997) examined the relationships between student achievement and school climate. The hypothesis of their study was that all aspects of school health are positively related to student achievement. The researchers found that stronger overall organizational health, or climate, of the school was related to higher levels of student achievement in basic skills.

Educational researchers have suggested through their research that there may also be a relationship between principal influence and the effectiveness of their schools (Dow \& Oakley, 1992). Schools with a positive climate have been shown to positively impact students (Hoy, 1972). A principal's leadership style influences the climate that, in turn, impacts student performance.

Standardized test scores have evolved as an important statistic used to assess student performance and school performance. The method by which the Florida Department of Education determines the level of success each school has in implementing the Sunshine State Standards (SSS) is by administering Florida's Comprehensive Assessment Test (FCAT) to students beginning in third grade and ending 
in $10^{\text {th }}$ grade. Results of the FCAT are used to gauge students' learning gains as they advance through grades 3-10 (Smith, 2009).

In addition to assessing students' individual test scores, the state of Florida publishes performance levels of each public school on its website by posting total points earned by schools, a product of student performance on the FCAT, as well as by using an academic grading scale of "A", "B", “C", "D”, or "F”. Information regarding school grades is largely reported in the media throughout the state. Comparing the performance of schools on the FCAT, and their ensuing grades, has become common practice in Florida.

\section{The Purpose of the Study}

Improving the level of school performance in the United States has become a national priority (Marzano, 2000). In this work, the researcher investigated Miami-Dade County Public Schools in order to determine if there is a relationship between instructional staff members' perceptions of their school's principal, a derivative of the district's school climate studies, and their schools' grades. An examination of the relationship between instructional staff members' perceptions of their schools' principals and their schools' grades was undertaken.

\section{Research Question}

The quantitative results of instructional staff members' responses to eight survey items within Miami-Dade County Public Schools' School Climate Survey was correlated with the number of points earned by schools, a determinant of school grades assigned by Florida's Department of Education, in order to answer the following question: Does a statistically significant relationship exist between instructional staff members' responses 
to survey items about their school's principals on the School Climate Survey and the number of points schools earn towards their school grades in Miami-Dade County Public Schools?

\section{Significance of the Study}

A study of principal leadership as it relates to school performance is important for several reasons. Federal mandates for student achievement through No Child Left Behind (NCLB) are likely to persist. As a result, identifying factors correlated with increased student achievement is paramount. Principal leadership indirectly impacts the performance of teachers under their leadership as well as the climate and culture of the building (Stewart, 2008). A study focusing on school climate factors as they relate to principal leadership and, subsequently, student achievement is a timely concern considering the urgency and scope of the performance demands that schools, districts, and states face today.

\section{Delimitations}

1. The present study was delimited to one school district in the state of Florida.

2. The only standardized measure of school performance used in this work was the grading system used by Florida's Department of Education.

3. The method used to determine the climate of the school, the School Climate Survey, was a survey given to instructional staff members, parents and students. This study was delimited to School Climate Survey questions related to instructional staff members' perceptions of principal leadership.

4. The method used to determine the climate of the school for this research was delimited to instructional staff members' responses on the School Climate Survey. 
Miami-Dade County Public Schools did not invite clerical employees, security monitors or custodial staff to participate in the School Climate Survey.

\section{Limitations}

Responses to School Climate Surveys are voluntary and anonymous. Even though response rates for this survey were considered more than adequate (Miami-Dade County Public Schools, 2009), staff members who chose not to respond to the survey could have altered findings if their responses were included.

\section{Definition of Terms}

Principal leadership. As perceived by teachers, principal leadership within this study encompassed items on the School Climate Survey that concerned: administrative abilities, public relations skills, interpersonal skills, the ability to deal with conflict, response time to concerns, receptiveness to criticism and support of teachers.

School climate. For the purpose of this study, school climate was defined by the researcher as the internal and external characteristics of a school (Hoy \& Hannum, 1997; Hoy \& Miskel, 1996). School climate is influenced by, and further described by the researcher as: (a) relationships built within the school community, (b) teachers' experiences, and (c) teachers' collective perceptions. This study looked at school climate, both internally and externally, as it is related to teachers' perceptions about principal leadership.

School performance. The standardized measure of school performance used in this study was points earned, a determinant of school grades, as a result of the cumulative performance of students on the 2009 FCAT. Given to students beginning in third grade and ending in $10^{\text {th }}$ grade, the FCAT is a criterion-referenced test that consists of multiple 
choice as well as open-ended questions. Student scores on math, reading, science, and writing were used to determine school grades. Additionally, the percentage of students tested as well as whether or not the lowest scoring $25 \%$ of students in reading and math made adequate yearly progress also impacted the total number of points earned by a school, which translated to the school's grade.

\section{Organization of Dissertation}

After this introductory chapter, the dissertation is organized into four additional chapters. The second chapter deals with the review of the literature. The third chapter then turns to a detailed discussion of the methodology used in this study. The fourth chapter presents the results of the research as they relate to the research question. The fifth and final chapter discusses the findings of this study and makes recommendations for future research and practice. 


\section{CHAPTER II}

\section{REVIEW OF LITERATURE}

Researchers have explored the importance of a positive school climate in creating a productive environment in which students are likely to succeed. Researchers have also focused on the impact that principal leadership has on school climate. Due to national and state demands, school performance will continue to be the focus of many research projects. This study linked the two concepts of: (a) principal leadership and (b) school performance. This chapter will describe and analyze selected works from researchers who focus on principal leadership, the impact of principal leadership on school performance, and the impact of school climate on school performance.

\section{Principal Leadership}

The role of the principal in American schools has been in a constant state of change since its emergence. Discussions have focused on whether the principal is a manager of the building or a leader of the school. Additionally, there has been dialogue regarding principals' expectations in regard to curriculum and instruction.

The emergence of the school principal began in the mid-nineteenth century (Rousmaniere, 2007). With the formation of schools in urban areas, a head teacher emerged in many districts to help guide or lead the other teachers in the school. As Rousmaniere pointed out, the lead teacher or principal teacher was the authority in the school, organized curriculum, was the disciplinarian, and supervised operations. With the continuation of urbanization in America, the development of the principal's position continued through the end of the nineteenth century when most urban schools had a principal. The role was very diverse in that some systems used the principal primarily as 
a teacher with minor operational duties while others used the principal as a clerk with record keeping duties.

Into the twentieth century, the role of the principal continued to develop from teacher to administrator with professional requirements and licensing becoming required for the position of principal. For much of the twentieth century, the role of the principal was that of manager where the principal was expected to uphold district mandates, manage personnel, manage the budget, and handle other operational issues (Usdan, McCloud, \& Podmostko, 2000). As American education moved into a new era of accountability in the later part of the past century, this role necessitated the inclusion of leadership. As Cawelti (1984) stated, "Continuing research on effective schools has verified the common sense observation that schools are rarely effective, in any sense of the word, unless the principal is a 'good' leader" (p. 3). Usdan and colleagues (2000) further developed their description of this role of the principal by stating, "principals today must serve as leaders for student learning” (p. 2). Fulfilling the role of school principal requires that leaders have an understanding of academic content, strengthen teachers' skills, gather and use data as well as motivate stakeholders to improve student performance (Usdan et al., 2000).

The leadership theory that has the most abundant presence in the current literature is that of transformational leadership. Transformational leadership centers around the idea of getting everyone involved in decision-making. "The overriding element of successful leadership is to involve people in the process of leading" (Horan, 1999, p. 21). Most explanations of transformational leadership begin with distinguishing it from transactional leadership. In transactional leadership the leader is concerned with the basic 
needs of the person through a reward system in exchange for favorable group or organizational outcomes. Transformational leadership's aim extends to reaching higher level needs through empowerment and inspiration.

Theories of transformational leadership have the following five common leader characteristics: creative, interactive, visionary, empowering, and passionate (Hackman \& Johnson, 2000). Originating as a model that helped leaders guide their schools into the twenty-first century, transformational leadership occurs when people raise one another to higher levels of motivation (Kouzes \& Posner, 2002; Leithwood, 1992).

Transformational leaders tend to be proactive and engaged in bringing about positive change; proactive people tend to work harder and persist in achieving goals more readily where others tend to give up, especially in the face of adversity (Kouzes \& Posner, 2002). In a school setting, a transformational leader (a) develops and maintains a positive school culture, (b) promotes teacher development, (c) helps the school solve problems collaboratively (Liethwood, 1992; Pepper \& Thomas, 2002).

In a very well known transformational theory, Kouzes and Posner (2002) list and describe the following as the five practices of exemplary leaders: Model the Way, an interactive approach to leadership; Inspire a Shared Vision, a visionary approach to leadership; Challenge the Process, a creative approach to leadership; Enable Others to Act, an approach to leadership that focuses on empowering others; and Encourage the Heart, a passionate approach to leadership. Model the Way refers to leading by example; exemplary leaders motivate followers by setting the example through direct involvement in the organization's mission. Inspire a Shared Vision means the leader is able to formulate, verbalize, and create enthusiasm for a vision of the organization. To create a 
desire to strive for the organization's goals, the leader must motivate the followers by relating to their personal goals and ambitions. Challenge the Process is the leader's ability to look for and choose innovative ways to improve the organization. The leader must study the organization and its people to determine the best course of improvement to lead the organization to become more. The category Enable Others to Act is the leader's ability to create teamwork and trust and to empower followers to work toward the organization's goals. Finally, Encourage the Heart refers to the leader's resilience to keep motivating and encouraging the followers through the exhaustion and frustration that often occurs with change.

Sergiovanni (1996) has argued that schools should not adopt corporate models for leadership. Instead, leaders should make decisions based on the shared values of the community. According to Sergiovanni, the purpose of leadership is to "transform the school into a moral community" (p. 45). The role of the principal should be to gather the stakeholders to engage and guide them in discussion and creation of the mission of the school.

Sergiovanni (1996) has explained that school leaders need to perform the following nine tasks in order to gain the confidence of those they lead:

1. Purposing: using a moral voice to transform a shared vision into a covenant that becomes the compelling force guiding the actions of principals, teachers, parents, and students.

2. Maintaining harmony: building consensus based on the shared vision and respecting individual differences of the stakeholders. 
3. Institutionalizing values: translating the shared vision into practices and norms that guide behavior.

4. Motivating: providing a balance between the psychological and cultural needs of the stakeholders.

5. Managing: providing and enacting the daily procedures that make up an efficient and effective school.

6. Explaining: working to relate requests for action directly to the common vision established by stakeholders.

7. Enabling: providing the resources necessary to achieve as well as removing the obstacles that stand in the way of accomplishing the common goal.

8. Modeling: living according to the purposes and values of the community in thought, word, and action.

9. Supervising: providing the oversight necessary to ensure that goals are accomplished. (pp. 88-89)

Sergiovanni (1996) believes that it is essential for leaders to mobilize communities to face their problems and make progress toward common goals. Schools need leaders who promote understanding and problem solving in order to create communities that engage stakeholders in achieving goals. The change strategies used by school leaders should be norms-based and include professional socialization, purposing, shared values, collegiality, and interdependence.

Similar to the ideas expressed by Sergiovanni, Heifetz (1994) has posited that the role of the leader is to mobilize people to tackle problems through the process of adaptive 
change. Using several examples from history, Heifetz has explained that the responsibility of a leader is to engage the stakeholders in the process of adaptive work.

In a study based on the broad scope of human resources, Norton (1999) asked 100 elementary and secondary principals to detail their responsibilities. It was found that $79 \%$ of the principals rated the following processes as demanding most of their time: organizational climate and staff selection, development, and evaluation. While the general conclusion of that study was that the principal assumes a significant leadership role in the effective administration of the human resource processes, the notion that the leader of the school also has primary responsibility for the climate of the organization is significant. Norton's study illustrates the notion that principals accept the primary responsibility for establishing a positive school climate. Norton concluded that administering all of the human resource responsibilities is an essential component to creating school programs of quality and the principal plays a primary role in each, including creating a positive school climate.

\section{Impact of Principal Leadership on Student Performance}

Actions of the principal can have widespread impact on many students. Effective educational leadership makes a difference in improving student learning (Leithwood \& Jantzi, 2000; Nettles \& Herrington, 2007). While there is evidence that a relationship between principal behavior and student achievement exists, it is unclear which specific

principal behaviors contribute to increased student learning. Because causal relationships are unclear, researchers' focus on the direct effect of principal behavior on student learning has been replaced by a focus on the overall influence principals' behavior has on 
student achievement through their interaction with teachers and the school environment (Nettles \& Herrington, 2007; Witziers, Bozkers, \& Kruger, 2003). This section reviews the literature focusing on the overall influence of principal leadership on student achievement.

Many researchers have described the traits of an effective instructional leader (Heck et al., 1990; Nettles \& Herrington, 2007; Marzano, Waters, \& McNulty, 2005; Saphier, King, \& D’Auria, 2006); several factors are common in the general literature on important traits of an effective leader. Blasé and Blasé (2000) assert that effective school leadership must include the principal in the role of the instructional leader. An instructional leader must: (a) give feedback, (b) model effective instruction, (c) solicit opinions, (d) make suggestions, (e) support collaboration, (f) provide professional development opportunities, and (g) give praise for effective teaching (Blasé \& Blasé, 2000).

Stakeholder involvement as a descriptor of effective school leadership involves the principal's ability to (a) build leadership capacity in teachers and staff, (b) encourage team focus on school goals, (c) use efficient and flexible organizational skills, and (d) distribute leadership throughout the school (Rea, McLaughlin, \& Walther-Thomas, 2002).

High expectations for student performance held by the principal are an important component of effective school leadership. Consistently communicating expectations to students has been correlated with increasing student achievement in schools (Leithwood \& Jantzi, 2000). Hand in hand with high expectations for students, effective principals also have high expectations for staff; effective school leaders expect teachers to put 
student achievement before all else and focus time management toward instructional priorities (Nettles \& Herrington, 2007). Hoy and Hannum (1997) refer to this high expectation for performance as collegial influence. Finally, professional development is an area that has been heavily researched and supported in that much of a principal's success comes from the opportunities the principal provides for the staff (Dufour \& Berkey, 1995; Leitner, 1994; Nettles \& Herrington, 2007).

The leadership of the principal affects, either positively or negatively, the learning and working environment of students and teachers (Pepper \& Thomas, 2002). Principal support influences the feelings teachers have about themselves and their work. Teachers characterizing principals as supportive (a) found work more rewarding (b) enjoyed a more productive and motivating work environment, (c) demonstrated lower turnover rates, and (d) experienced lower job-related stress and burn-out. Consequently, these factors may have affected how successful their students were.

The principal has the power to establish and guide the positive progress of a school and develop and nurture relationships within the school community that impact the overall school climate (Day, 2000; Pepper \& Thomas, 2002). The principal must establish an atmosphere of trust and camaraderie, as opposed to an atmosphere of competition and confrontation. Principals and teachers should interact in such a way that demonstrates mutual respect and caring, a relationship the students will witness and hopefully learn from.

\section{Impact of School Climate on Student Performance}

Schools impact students largely through their climate (Stewart, 2007). According to an ecological model of human development (Brofenbrenner, 1979), the academic 
achievement of students is influenced by many factors in their personal environments, but also by many aspects in their school environments as well. Many factors are often categorized under the term school climate (Hoy \& Hannum, 1997). These factors, in this discussion of school climate, may include but are not limited to (a) social/cultural factors, (b) discipline issues, (c) teacher attitudes/student-teacher relationships, and (d) the condition of the school building. School climate can also be defined as the beliefs, values, and attitudes shaping the interactions between the principals, teachers, and students which set guidelines of acceptable behaviors and norms for the school (Koth at el., 2008). School climate and its many dimensions (e.g., social/minority factors, discipline, teacher attitudes/student-teacher relationships, and school building condition) have been shown to have an impact on student achievement (Benner, Graham, \& Mistry, 2008; Carbonaro, 2005; Stewart, 2007; Uline \& Tschannen-Moran, 2008).

Several instruments have been developed over the years to measure and describe the climate of a school (Halpin \& Croft, 1963; Hoy \& Clover, 1986; Hoy, Hoffman, Sabo, \& Bliss, 1996; Hoy \& Miske, 1991; Pace \& Stern, 1958; Stern, 1970). Schools with a positive climate can be described as open, healthy, humanistic, or participative depending on the specific research tool that is utilized (Halpin \& Croft, 1963; Likert, 1961; Willower, Eidell, \& Hoy, 1986). In contrast, schools with a negative climate are often described as closed, unhealthy, custodial, and exploitive (Halpin \& Croft, 1963; Likert, 1961; Willower, Eidell, \& Hoy, 1986).

In research surrounding the Effective Schools Movement, school climate has been identified as an important factor in explaining the difference in seemingly similar schools (Leithwood, 1992). Hannum (1994) explained that there is a strong positive correlation 
between schools with open climates and school performance. A positive school climate has been linked to academic achievement (Benner et al., 2008; Hoy \& Hannum, 1997; Koth, Bradshaw, \& Leaf, 2008; Stewart, 2007; Uline \& Tschannen-Moran, 2008) while negative school climate has been linked to student misconduct and aggression (Koth et al., 2008; Wilson, 2004).

As the leader of the school, the principal plays a key role in establishing the climate (Hoy \& Forsyth, 1986). How people react to the decisions made and the procedures established by the principal results in feelings that can be measured and described as the climate of the school. More than any other person in the school setting, the principal has the ability to influence the climate of the school. Therefore, a conscientious principal should work towards creating a positive climate within the building. Deal and Peterson (1990) explain this in the following excerpt.

We know, for instance, that effective principals generally have a "sixth sense" about the values and beliefs that shape their school community. They are able to tap into and harness those beliefs as a positive force for students. These principals nurture a sense of purpose and playfulness in the daily life of school. Happily, research suggests that these abilities be understood and learned. (p. 24)

Teachers who feel supported by their principals are more likely to take risks that will improve their quality of instruction in the classroom (Hoy \& Hannum, 1998). Sufka and George (2000) found that effective teachers establish relationships with students and take the time to establish a good rapport with the class. Hunter-Boykin and Evans (1995) stated that a better academic environment is a result of high teacher morale. In a study by Stewart (2008) it was concluded that school contexts where there was cooperation 
between principals and teachers, support for teachers, and clear expectations could be positively related to higher levels of student achievement in classrooms. Positive teacher attitudes and behaviors have been directly related to student achievement; while the converse is also true, teacher disengagement is negatively related to student achievement (Hoy, Hannum, \& Tschannen-Moran, 1998). Wentworth (1990) stated that low morale has a negative effect on student achievement. Araki (1982) performed a three-year study to examine leadership in the public and private schools of Hawaii. He found that both the perceived leadership of the principal and teacher morale level were significantly correlated to student SAT scores. Houchard (2005) analyzed the relationship that teacher morale has with student achievement measured by North Carolina's End-of-Course Test scores. He found that teacher morale was positively correlated to these test scores. If the leadership of the principal is to have any effect on student achievement, it must be linked to activities within the classroom that make a difference in teaching and learning.

In their roles as school leaders, principals may affect the feelings that teachers have about themselves and their work (Blasé \& Blasé, 2000; Pepper \& Thomas, 2002). As a result of the pervasive influence principals have on their staff members, principals may directly affect the performance of teachers (Leithwood \& Jantzi, 2000; Nettles \& Herrington, 2007; Stewart, 2008). Studies corroborate that open, supportive principals can be related to higher levels of achievement in schools (Hannum, 1994; Hoy \& Hannum, 1997; Leithwood, 1992; Stewart, 2008). Research shows that principal leadership and school climate impact student performance. In nearly every case, the literature shows that positive leadership traits or behaviors are accompanied by positive teacher morale. Studies also support a significant relationship between teacher morale 
and student academic achievement. Thus, the leadership of the principal may also play a vital role in teacher morale and affect student achievement.

\section{Summary of Review of Literature}

Miami-Dade County Public Schools' School Climate Survey includes eight statements that link principal leadership with school climate, thereby connecting the themes of this review of literature. Statements within the School Climate Survey that focus on principals representing their schools in a positive manner, as well as principals dealing with conflict constructively, can be tied to theories of transformational leadership as well as the Effective Schools Movement (Kouzes \& Posner, 2002; Leithwood, 1992). Furthermore, statements that address the response time of principals to teachers' concerns as well as principals' administrative duties can be aligned with Sergiovanni's (1996) description of managing and supervising within transformational leadership. Segments of the Effective Schools Movement can also be associated with Miami-Dade County Public Schools' School Climate Survey, through statements tied to teachers' perceptions of the respect they receive from their principals, how principals respond to constructive criticism and the degree to which teachers believe they are supported by their principals (Blasé \& Blasé, 2000). With a link between school climate and academic achievement (Benner et al., 2008; Hoy \& Hannum, 1997; Koth, Bradshaw \& Leaf, 2008; Stewart, 2007; Uline \& Tsachannen-Moran, 2008), and the principal playing a key role in establishing a school's climate (Hoy \& Forsyth, 1986), Miami-Dade County Public Schools' School Climate Survey connects these concepts, giving a voice to teachers' perceptions of their principals' leadership skills. 


\section{CHAPTER III \\ METHODOLOGY}

The purpose of this study was to examine the relationship between instructional staff members' perceptions of principal leadership and school performance, in terms of school grades, in Miami-Dade County Public Schools. Instructional staff members’ perceptions of principal leadership were studied as a derivative of Miami-Dade County Public Schools' 2009 School Climate Surveys. Schools and their instructional staff members' perceptions of principal leadership were categorized by the number of points earned in a statewide FCAT performance evaluation process that was determined by Florida's Department of Education for the 2008-2009 school year. Categorizing schools by the number of points they earned, a determinant of school grades, helped to provide information about whether or not instructional staff members' perceptions of principal leadership on a school climate survey could be correlated with school performance.

The problem studied was: Is there a positive relationship between instructional staff members' perceptions of their principals and the performance of schools? To investigate this problem, the following research question and research hypothesis were analyzed: Does a statistically significant relationship exist between instructional staff members' responses to survey items about their school's principals on the School Climate Survey and the number of points schools earn towards their school grades in Miami-Dade County Public Schools? Hypothesis: A statistically significant relationship exists between instructional staff members' responses to survey items about their school's 
principal on the School Climate Survey and school grades in Miami-Dade County Public Schools.

This study complements the work of Goddard, Sweetland and Hoy (2000), Hannum (1994), Hoy and Forsyth (1986), Hoy and Hannum (1997), Leithwood (1992) as well as Stewart (2008), who found that a strong positive correlation exists between schools with positive climates and high levels of school performance.

The methodology of the study is fully explained in this chapter. Detail is used to explain the research design, the participants, the instruments, the procedures, and the analysis of data. The chapter concludes with an explanation of the analysis of the data.

\section{Research Design}

This study explored relationships between variables, which made the research design ex-post-facto (Newman \& Benz, 1998). Ex-post-facto research is appropriate when the independent variable in a study cannot be influenced or manipulated (Newman, Newman, Brown, \& McNeely, 2006). Within ex-post-facto research designs, the relationship between variables is inferred without drawing a parallel to causation (Kerlinger \& Lee, 2000).

Within ex-post-facto research designs, three primary weaknesses can be found: (a) independent variables cannot be manipulated because the data being analyzed already exists, (b) participants cannot be randomized because they were predetermined before the study ensued, (c) the inability to manipulate data may result in findings being interpreted incorrectly (Kerlinger \& Lee, 2000; Newman, Benz, Weis, \& McNeil, 1997). 
Furthermore, as results for this study cannot be related to an independent variable, causation cannot be determined.

Ex-post-facto research designs tend to have lesser degrees of internal validity than experimental designs. However, they can have high degrees of external validity, which means the results may be generalized beyond the study itself (Newman et al., 2006). Lower degrees of internal validity are present due to the absence of experimental controls (Newman et al., 2006). Within the case of this study, higher degrees of external validity were achieved due to the large sample size being used.

\section{Participants}

The study took place in Miami-Dade County Public Schools, which served approximately 345,000 students for the 2008-2009 school year and employed approximately 21,000 teachers.

Instructional staff for the 2008-2009 school year included 21,260 teachers, 916 guidance counselors, 148 school social workers, 225 school psychologists, 344 librarians and audiovisual staff, and 504 other professional staff (Statistical Highlights, 2009). Of the 21, 260 teachers reported, there were 9,143 elementary teachers, 6,231 secondary teachers, 3,659 exceptional student education teachers, and 2,227 vocational/adult/other teachers employed for the 2008-2009 school year (Statistical Highlights, 2009).

Within the 2008-2009 school year, the school district contained 415 schools: 210 elementary, 37 K-8 center, 80 middle, 71 senior high, 4 combined, and 13 alternative/special education. Of the students enrolled in this school district for the 20082009 school year, 31,457 were classified as White Non-Hispanic, 88,610 were classified 
as Black Non-Hispanic, 215,896 were classified as Hispanic and 9,187 were classified as Other (Statistical Highlights, 2009). With regard to gender, 177,177 students were male and 167,973 were female (Statistical Highlights, 2009). Of the 345,150 students enrolled for the 2008-2009 school year, 54,284 students were enrolled in Exceptional Student Education programs, 39,407 students were enrolled in Magnet Programs, 203,524 students were enrolled in Advanced Placement classes and $63.4 \%$ of students were eligible for free or reduced price lunch (Statistical Highlights, 2009).

\section{Instruments}

\section{Florida School Grades}

The instruments used in this study were Florida's Department of Education school grades for Miami-Dade County Public Schools and Miami-Dade County Public Schools’ School Climate Survey for instructional staff members. School grades were first issued in 1999 as part of the Florida Legislature's A+ Plan for Education (History of School Grades, 2010). School Climate Surveys have been distributed to parents, students and instructional staff members within Miami-Dade County Public Schools since the early 1990s (Miami-Dade County Public Schools, 2009).

Since 1999, students' scores on the FCAT have been the foremost criterion in assigning school grades (Smith, 2009). In 2001, school grades evolved to include FCAT results of students enrolled in grades 3-10, then in 2002 student learning gains were considered as a factor used to help determine school grades (History of School Grades, 2010). In 2007, performance on the Science portion of the FCAT, as well as learning gains of the lowest scoring $25 \%$ of students in school, and the scores of students re-taking 
the FCAT were added as determinants of school grades (History of School Grades, 2010).

School grades for the 2008-2009 school year were determined by calculating points that are related to eight measures of achievement as well as two additional conditions. Florida Administrative Code Rule 6A-1.09981 describes the eight performance measures included in the overall grade for a school:

1. One point for each percent of students who meet high standards by scoring at or above FCAT Achievement Level 3 in reading on a 5point scale.

2. One point for each percent of students who meet high standards by scoring at or above FCAT Achievement Level 3 in mathematics on a 5-point scale.

3. One point for each percent of students who meet high standards by scoring at or above FCAT Achievement Level 3 in science on a 5point scale.

4. One point for each percent of students who meet high standards by scoring 3.5 or higher on the FCAT writing assessment on a 6-point scale. In the event that there are not at least 30 eligible students tested in writing, the district average in writing is substituted.

5. One point for each percent of students making learning gains in reading. 
6. One point for each percent of students making learning gains in mathematics.

7. One point for each percent of the lowest performing students making learning gains in reading. In the event that there are not at least 30 eligible students, the school's reading learning gains are substituted.

8. One point for each percent of the lowest performing students making learning gains in mathematics. In the event that there are not at least 30 eligible students, the school's mathematics learning gains are substituted. (Smith, 2009)

Along with calculating the points listed above, in 2008-2009 schools were evaluated on two other conditions. The first condition considered the percentage of students tested in each school. A school working to earn a grade of "A" had to test at least $95 \%$ of their eligible students. All other school grades could be earned by schools that tested a minimum of $90 \%$ of eligible students. If fewer than $90 \%$ of eligible students were tested, the school initially received an incomplete. Florida's Department of Education investigated all schools earning incompletes. Schools with student-testing percentages that remained lower than $90 \%$ may have earned a school grade, but the school's final grade would be lower than the total points accumulated.

The second condition considered adequate yearly progress of students. Schools earning enough points for a grade of " $\mathrm{A}$ " were required to show adequate yearly progress of their lowest scoring $25 \%$ of students in both reading and mathematics for the 2008 2009 school year. Schools earning enough points for a grade of "B" or " $C$ " were required 
to show adequate yearly progress of their lowest scoring $25 \%$ of students in both reading and mathematics for the 2008-2009 year or the previous school year. The lowest scoring $25 \%$ of students encompassed students scoring at achievement levels 1-3 on the reading and mathematics subtests of the FCAT in each grade. Schools failing to meet this criterion saw their school grades reduced by one letter grade.

In 2009, there was an eight-step process for calculating school grades. The first step was to identify schools that would be graded. Department of Juvenile Justice schools did not earn school grades and Alternative schools had the option to elect to receive an alternative school improvement rating rather than a school grade (Smith, 2009). The second step was to identify students who would be included in the grading process. Students enrolled for two academic years, including speech impaired students, gifted students, hospital homebound students, and English language learner students enrolled in English for Speakers of Other Languages (ESOL) for more than two years were included in the calculation of school grades. The third step was to obtain students' FCAT scores (Smith, 2009). The fourth step involved determining percentage points for each of the eight performance measures. The fifth step was to determine retake bonus points for high school students in $11^{\text {th }}$ and $12^{\text {th }}$ grade who took the FCAT in $10^{\text {th }}$ grade, a graduation requirement, and did not pass the test. The sixth step was to determine the percentage of students tested. The seventh step was to determine whether or not the lowest scoring $25 \%$ of the school's student population made adequate yearly progress in reading as well as mathematics. The eighth and final step was to calculate the total points earned for each school and then determine the school grade (Smith, 2009). 
After all points were calculated, and all special conditions were investigated, earned points were added together and applied to Florida Department of Education's school grading scale, shown below in Table 1.

\begin{tabular}{|c|c|}
\hline \multicolumn{2}{|c|}{2009 School Grading Scale } \\
\hline Grade & Total Points \\
\hline A & 525 and above \\
\hline B & $495-524$ \\
\hline $\mathrm{C}$ & $435-494$ \\
\hline $\mathrm{D}$ & $395-434$ \\
\hline F & Less than 395 \\
\hline
\end{tabular}

\section{School Climate Survey}

School Climate Surveys have been distributed to parents, students and staff members in Miami-Dade County Public Schools since the early 1990s and their reliability has been tested in previous years by Research Services (Miami-Dade County Public Schools, 2009). Survey items remain the same from school year to school year so that information based on tens of thousands of responses regarding how different subgroups feel about their school may be gathered and patterns may be analyzed (MiamiDade County Public Schools, 2009). The parent survey contains 35 survey items, the student survey contains 27 survey items and the staff survey contains 35 survey items. With the exception of the last statement on each of the groups' surveys, all of the survey items use a 5-point Likert scale: SA (Strongly Agree), A (Agree), U 
(Undecided/Unknown), D (Disagree), and SD (Strongly Disagree). The last survey item on each survey asks participants to give their school an overall letter grade of "A", "B", "C", "D", or "F".

Cronbach's Alpha, an internal consistency measure, was used to estimate reliability coefficients for staff forms of the School Climate Survey (Cronbach, 1951; Miami-Dade County Public Schools, 2009). The usefulness of the School Climate Survey as a reliable instrument is supported by the reliability estimate for the staff form, alpha=0.88 (Miami-Dade County Public Schools, 2009). According to Miami-Dade County Public Schools Research Services (2009), with samples as large as the ones being used by Miami-Dade County Public Schools' Research Services, it can be said with 95\% certainty that the findings of the School Climate Survey have a statistical precision of plus or minus $1 \%$ from what they would be if the entire school population had been surveyed (Miami-Dade County Public Schools, 2009).

Through follow-up telephone surveys performed by Research Services in previous years, it was determined that the results of Miami-Dade County Public Schools' School Climate Surveys are, "more than minimally adequate for providing meaningful data," and the, "survey results are exceedingly reliable" (Romanik \& Froman, 1992).

Within the School Climate Survey for staff members, eight staff survey items were analyzed for this study. Those eight survey items were:

7. My principal is an effective administrator.

8. My principal represents the school in a positive manner.

9. My principal demonstrates good interpersonal skills.

10. My principal deals with conflict constructively. 
11. My principal responds in a reasonable time to my concerns.

12. My principal treats me with respect.

13. My principal is receptive to constructive criticism.

14. My principal is supportive of teachers. (Appendix A).

In 2002, Miami-Dade County Public Schools published a Research Brief discussing the validity of the eight items related to principal leadership on the Staff Form of the School Climate Survey. Within this Research Brief (2002), it was noted that there is a general reliability between annual personnel evaluations of principals by region directors and instructional staff members' ratings of their principals on the School Climate Survey. Miami-Dade County Public Schools’ 2002 Research Brief noted, "Analysis indicated that the items are highly correlated and can be thoughts of as comprising a leadership effectiveness factor" (p.1). Even though they do not cover every aspect of a principal's responsibilities, the eight survey items selected from the School Climate Survey for this study are a suitable instrument because they validly measure instructional staff members' perceptions of their principals, thereby playing a key role in establishing the climate of their schools (Hoy \& Forsyth, 1986; Research Brief, 2002).

\section{Procedures}

According to the Statewide Assessment Calendar (2009), students took the writing portion of the FCAT February 10, 2009- February 12, 2009. The reading, math and science portions of the FCAT were administered sometime between March 10, 2009 and March 19, 2009 (Statewide Assessment Calendar, 2009). After students completed the FCAT and their scores were calculated, Florida's Department of Education began their eight-step process for calculating schools' grades (Smith, 2009). Florida's 
Department of Education released the total number of points earned by each school as well as school grades for the 2008-2009 school year in June of 2009.

Out of the total schools in Miami-Dade County Public Schools for the 2008-2009 school year, 367 of those schools had school grades posted on Florida's Department of Education Website for the 2008-2009 school year (Florida School Grades, 2011).

\begin{tabular}{|c|c|c|}
\hline \multicolumn{3}{|c|}{$\begin{array}{l}\text { Table } 2 \\
\text { Miami-Dade County Public } \\
\text { Schools Grade Frequencies } \\
(n=367)\end{array}$} \\
\hline Grade & Frequency & Percent \\
\hline $\mathrm{A}$ & 210 & 57.2 \\
\hline B & 55 & 15.0 \\
\hline $\mathrm{C}$ & 64 & 17.4 \\
\hline $\mathrm{D}$ & 26 & 7.1 \\
\hline $\mathrm{F}$ & 12 & 3.3 \\
\hline
\end{tabular}

Of the 367 Miami-Dade County Public Schools identified as earning school grades on Florida's Department of Education website, 338 of them also had School Climate Survey results posted by individual school for the 2008-2009 school year on MDCPS' Research Services website (Miami-Dade County Public Schools, 2009).

In 2008-2009, invitations to complete Miami-Dade County Public Schools' School Climate Survey Staff Form were distributed to 25,000 instructional staff members with a return rate of 75\% (Miami-Dade County Public Schools, 2009). Instructional staff members were notified of the opportunity to complete the School Climate Surveys by their administrators as well as by the school district via e-mail. Instructional staff members who volunteered to complete the survey signed a school-site roster indicating 
they received a sealed envelope containing a unique identification number, password and instructions for completing the survey on-line (Appendix B). By signing a school-site roster, the district attempted to prevent instructional staff members from filling out the School Climate Survey more than one time.

Participants did not have to complete the on-line surveys at their work locations, they could access the on-line surveys from any computer. School climate surveys were available on-line for 1 month, from January 2009 to February 2009. An outside Internet service company, Infopoll, monitored identification numbers, passwords and the progress of survey completion by instructional staff members (Appendix C). After instructional staff members accessed the on-line School Climate Survey with their unique identification numbers and passwords, they were prompted to find their school's location number and complete the survey for their school location (Appendix C). Once instructional staff members' randomly selected unique identification numbers and passwords were used they could not be used again. Instructional staff members were told that their responses were anonymous.

Due to the fact that all data used for this study is public domain and can be found on-line, Miami-Dade County Public Schools' Research Services did not require the researcher to submit a Research Review Form for the use of Miami-Dade County Public Schools' School Climate Survey data (T. Chebbi, personal communication, August 30, 2011). Within the Research Services website, schools' individual survey responses have been averaged according to a 5-point Likert scale: SA (Strongly Agree), A (Agree), U (Undecided/Unknown), D (Disagree), and SD (Strongly Disagree). The researcher gathered individual schools' averaged staff survey responses to survey items 7-14 for the 
2008-2009 school year by going online to Miami-Dade County Public Schools' Research Services website and accessing individual schools' Staff Form reports (Appendix A).

\section{Analysis of Data}

Quantitative data for this study was entered into MicroSoft Excel and then transferred into SPSS. Response categories within the School Climate Survey's 5-point Likert scale ranged from Strongly Agree to Strongly Disagree. Descriptive statistics, such as mean, standard deviation and frequencies, for school grades, points earned and responses to School Climate Survey items were run for each variable (Gall, Gall, \& Borg, 2003).

Pearson's correlation analysis was run to determine the relationship between schools' earned points and averaged survey responses (Healey, 2004; Hinkle, Wiersma, \& Jurs, 2003). Correlation coefficients indicated the strength as well as the direction of relationships between multiple variables concurrently (Healey, 2004; Hinkle, et al., 2003). Inter-correlations between the eight survey items were reported (Hinkle, et al., 2003).

The researcher originally intended to analyze data for statistically significant relationships using multiple linear regression analysis (Hinkle, et al., 2003; McNeil, Newman, \& Kelly, 1996). Through data analysis the researcher found that the School Climate Survey responses in this study are highly correlated and essentially convey the same message. Due to the fact that the correlations between this study's independent variables, the School Climate Survey responses, was very high, the researcher created a

composite variable from the School Climate Survey responses (Pallant, 2007). This 
composite variable, titled Principal Leadership Score, was analyzed for its correlation to points earned by schools.

The significance level, or alpha level $(\alpha)$, for this study was set at .05, which is a typical setting for the social sciences and helped to avoid Type I errors and Type II errors (Healey, 2004; Hinkle, et al., 2003). The possibility of a Type I error in the researchers' findings was further reduced by the good reliability estimates of the School Climate Survey findings by Miami-Dade County Public Schools. All results are presented in Chapter 4.

\section{Summary of Methodology}

This chapter described and explained the methods used in this study. It stated the type of research that was conducted as well as the research design. A depiction of the participants of the study was given along with a description of Florida's school grades and Miami-Dade County Public Schools' School Climate Survey. The procedure for grading schools and the procedure for collecting instructional staff members' School Climate Survey responses was discussed. The next chapter presents the findings of the study then the final chapter discusses these findings. 


\section{Chapter IV}

\section{DATA ANALYSIS}

This study examined the relationship between teachers' perceptions of their school's principals and school performance. Specifically, this study investigated whether schools' averaged teacher responses to survey items about their principals on MiamiDade County Public Schools' School Climate Survey could be correlated with schools' earned points, a derivative of Florida Department of Education's school grades. This chapter presents data analysis of Miami-Dade County Public Schools' eight School Climate Survey items related to principal leadership, data analysis of the correlation between points earned and school climate survey items, and data analysis of a composite variable of the eight School Climate Survey items.

\section{School Climate Surveys}

All eight School Climate Survey items were analyzed for distribution of mean percentages and standard deviations of teachers' responses (Appendix D). Much of the resulting data showed similar trends. For instance, each survey item showed a similar tendency of the mean percentages being highest in the Strongly Agree response category and then each response category decreasing subsequently behind the category before it. Still, some of the resulting data may shed light on how teachers perceive their principals, which is why items $7,9,12$, and 13 are discussed in further detail in the following pages.

For instance, survey item 7 had the highest mean percentage of Agree responses at

$32.6 \%$ (Table 3 ). This information is important because it can be related to Norton's (1999) 
findings that administrative duties are a part of the principal's primary responsibility for establishing a positive school climate. Table 3's findings can also provide further reflection with regard to the managing task described by Segiovanni (1996), which is one of nine tasks he believes helps principals gain the confidence of those they lead.

Table 3 ( $n=338)$

Distribution of Mean Percentage of Teachers and Standard Deviations for Item 7:

My principal is an effective administrator.

\begin{tabular}{lcc}
\hline \multicolumn{1}{c}{ Response } & $\begin{array}{c}\text { Mean } \\
\text { Percentage }\end{array}$ & $\begin{array}{c}\text { Standard } \\
\text { Deviation }\end{array}$ \\
\hline Strongly Agree & 52.8 & 20.8 \\
Agree & 32.6 & 12.7 \\
Undecided/Unknown & 7.7 & 6.8 \\
Disagree & 4.5 & 5.3 \\
Strongly Disagree & 2.6 & 4.4 \\
\hline
\end{tabular}

Table 4 describes item 9 , which has the highest mean percentage, $6.3 \%$, of teachers who Disagree with a survey item. This survey item also shared the highest mean percentage for Strongly Disagree, with a 3.6\% mean percentage in response to survey item 13.

As one can see, many teachers strongly agreed with survey item 9 (Table 4). Still, the fact that survey item 9 had higher mean percentages for the Disagree and Strongly Disagree response categories indicates that the principals being evaluated could likely work on their ability to build consensus and maintain harmony (Sergionvanni, 1996). Principals who build consensus and maintain harmony help to inspire a shared vision (Kouzes and Posner, 2002), which involves formulating and creating enthusiasm. The ability to inspire a shared vision amongst staff members speaks toward the interpersonal skills motivational principals need (Kouzes \& Posner, 2002). 
Table 4 ( $n=338)$

Distribution of Mean Percentage of Teachers and Standard Deviations for Item 9:

My principal demonstrates good interpersonal skills.

\begin{tabular}{lcc}
\hline \multicolumn{1}{c}{ Response } & $\begin{array}{c}\text { Mean } \\
\text { Percentage }\end{array}$ & $\begin{array}{c}\text { Standard } \\
\text { Deviation }\end{array}$ \\
\hline Strongly Agree & 52.7 & 20.8 \\
Agree & 30.3 & 11.8 \\
Undecided/Unknown & 7.1 & 5.7 \\
Disagree & 6.3 & 6.5 \\
Strongly Disagree & 3.6 & 5.4 \\
\hline
\end{tabular}

Table 5 shows the highest Strongly Agree mean percentage. In this case, item 12 had a Strongly Agree mean percentage of $61.7 \%$. Identifying the highest percentage score for Strongly Agree is helpful in this case because it may provide evidence of a singular behavior on the part of principals that has the largest positive influence on School Climate. For instance, principals who have the ability to enable others and create teamwork (Kouzes \& Posner, 2002), or principals that are Transformational Leaders (Sergionvanni, 1996), may inspire their teachers to feel respected, thereby positively impacting school climate.

Table 5 ( $n=338)$

Distribution of Mean Percentage of Teachers and Standard Deviations for Item 12:

My principal treats me with respect.

\begin{tabular}{lcc}
\hline \multicolumn{1}{c}{ Response } & $\begin{array}{c}\text { Mean } \\
\text { Percentage }\end{array}$ & $\begin{array}{c}\text { Standard } \\
\text { Deviation }\end{array}$ \\
\hline Strongly Agree & 61.7 & 18.0 \\
Agree & 28.7 & 12.5 \\
Undecided/Unknown & 4.6 & 4.5 \\
Disagree & 2.7 & 3.3 \\
Strongly Disagree & 2.3 & 3.6 \\
\hline
\end{tabular}


Finally, Table 6, with its information about item 13, is notable as well. This survey item has the lowest mean percentage for Strongly Agree, 47.7\%, as well as Agree, 25.4\%. Survey item 13 also had the highest mean percentage of Undecided/Unknown, $17.9 \%$, and its Strongly Disagree response was equal to survey item 9, 3.6\%.

With regard to Miami-Dade County Public Schools' School Climate Survey, Table 6's information sheds light on what could be perceived as Miami-Dade County Public Schools' principals' biggest weakness. Horan (1999) found that everyone in a school needs to be involved in the decision-making process. If teachers feel as though their constructive criticism of their principals is not valued, then it is possible that they will not feel motivated to become involved in their school's decision-making process. Additionally, Stewart (2008) has discussed the importance of cooperation between principals and teachers. Without the belief that principals are receptive to constructive criticism, teachers may be less likely to cooperate when they are being criticized. Likewise, Sergiovanni’s (1996) extensive research on Transformational Leadership speaks toward the importance of respecting individual differences. Without the ability to openly share constructive criticisms, it is likely that teachers will not feel their perspectives, or their differences, are being respected.

Table 6 ( $n=338)$

Distribution of Mean Percentage of Teachers and Standard Deviations for Item 13:

My principal is receptive to constructive criticism.

\begin{tabular}{lcc}
\hline \multicolumn{1}{c}{ Response } & $\begin{array}{c}\text { Mean } \\
\text { Percentage }\end{array}$ & $\begin{array}{c}\text { Standard } \\
\text { Deviation }\end{array}$ \\
\hline Strongly Agree & 47.7 & 19.5 \\
Agree & 25.4 & 10.3 \\
Undecided/Unknown & 17.9 & 9.9 \\
Disagree & 5.5 & 5.2 \\
Strongly Disagree & 3.6 & 4.7 \\
\hline
\end{tabular}


To obtain a clearer understanding of overall responses by survey item, each response category was given a score and then a total score was calculated. By finding the sum for each response category by survey item, the results of the School Climate Survey items could be consolidated and analyzed, making it easier to understand the data.

By listing survey item 12 with the highest mean, Table 7 supports Table 5's findings. Similarly, Table 7's results are in line with Table 6's results, as survey item 13 has the lowest mean. Perhaps Table 7's most important contribution is that it consolidates all of the schools' averaged School Climate Survey responses, succinctly demonstrating that all eight mean scores are high, falling in the Strongly Agree category. Moreover, the difference between the highest score, 4.45 , and the lowest score, 4.08 , is merely .37 points. In the same way, there is little variance between the range of standard deviations included in Table 7.

Table 7

Distribution of Mean Percentage of Teachers and Standard Deviations for Each Survey Item by 5-point scale

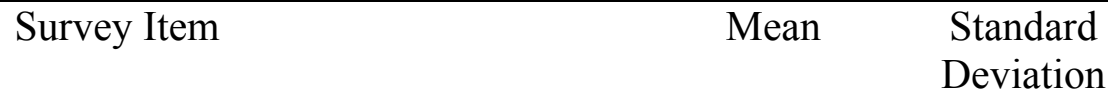

$\begin{array}{lll}\text { 7. My principal is an effective administrator. } & 4.29 & 0.43 \\ \text { 8. My principal represents the school in a positive manner. } & 4.42 & 0.37 \\ \text { 9. My principal demonstrates good interpersonal skills. } & 4.22 & 0.48 \\ \text { 10. My principal deals with conflict constructively. } & 4.19 & 0.46 \\ \text { 11. My principal responds in a reasonable time to my concerns. } & 4.32 & 0.39 \\ \text { 12. My principal treats me with respect. } & 4.45 & 0.34 \\ \text { 13. My principal is receptive to constructive criticism. } & 4.08 & 0.43 \\ \text { 14. My principal is supportive of teachers. } & 4.30 & 0.42\end{array}$

Note. $n=338$.

Note. $1=$ Strongly Disagree, $2=$ Disagree, $3=$ Undecided/Unknown, $4=$ Agree, $5=$ Strongly Agree 
In the next step, survey items were intercorrelated to show how they relate to each other in a pairwise fashion. The smallest intercorrelation was between survey item 11 and survey item 12 at .83 , which is a large intercorrelation (Table 8). The largest intercorrelation of .96 was found between survey item 10 and survey item 7 , as well as survey item 10 and survey item 14 (Table 8).

Table 8

Intercorrelations Between Survey Items

7. My principal is an effective administrator.

8. My principal represents the school in a positive manner.

9. My principal demonstrates good interpersonal skills.

10. My principal deals with conflict constructively.

$\begin{array}{llllllll}7 & 8 & 9 & 10 & 11 & 12 & 13 & 14\end{array}$

11. My principal responds in a reasonable time to my concerns.

12. My principal treats me with respect.

13. My principal is receptive to constructive criticism.

14. My principal is supportive of teachers.

Note. $n=338$.

Note. ${ }^{* *} \mathrm{p}<.01$

\begin{tabular}{cccccccc}
1 & - & - & - & - & - & - & - \\
$.94^{* *}$ & 1 & - & - & - & - & - & - \\
$.88^{* *}$ & $.92^{* *}$ & 1 & - & - & - & - & - \\
$.96^{* *}$ & $.95^{* *}$ & $.94^{* *}$ & 1 & - & - & - & - \\
$.91^{* *}$ & $.88^{* *}$ & $.85^{* *}$ & $.90^{* *}$ & 1 & - & - & - \\
$.85^{* *}$ & $.90^{* *}$ & $.93^{* *}$ & $.90^{* *}$ & $.83^{* *}$ & 1 & - & - \\
$.90^{* *}$ & $.91^{* *}$ & $.94^{* *}$ & $.94^{* *}$ & $.88^{* *}$ & $.92^{* *}$ & 1 & - \\
$.94^{* *}$ & $.94^{* *}$ & $.94^{* *}$ & $.96^{* *}$ & $.89^{* *}$ & $.92^{* *}$ & $.94^{* *}$ & 1 \\
\hline & & & & & & &
\end{tabular}

\section{Correlations Between Points Earned and School Climate Survey Items}

Table 9 shows that Pearson's $r$ was used to test the strength of the linear relationship between points earned by schools and school's averaged responses to School Climate Survey items. Survey items 8, 9, 12 and 13 had weak (less than .30) positive correlations to schools' earned points. Despite being considered weak, the lowest positive 
correlation was at .22 for survey item 9 (Table 9). Survey items 7, 10, 11 and 14 had moderate (above .30 ) positive correlations to schools' earned points (Table 9). In this case, despite being considered moderate, the highest positive correlation to schools' earned points was survey item 7 , at .35, which is on the lower end of the moderate scale (Table 9).

Table 9's data demonstrates that the weakest positive correlation between points earned and survey items, and the strongest positive correlation between points earned and survey items, had little variance.

Table 9

Correlations Between Points Earned and Survey Items

Survey Item

Pearson

Correlation

7. My principal is an effective administrator.

$.350 * *$

8. My principal represents the school in a positive manner.

$.294 * *$

9. My principal demonstrates good interpersonal skills.

$.220 * *$

10. My principal deals with conflict constructively.

$.304 * *$

11. My principal responds in a reasonable time to my concerns.

$.342 * *$

12. My principal treats me with respect.

$.281 * *$

13. My principal is receptive to constructive criticism.

$.295 * *$

14. My principal is supportive of teachers.

$.312 * *$

Note. $n=338$.

Note. ${ }^{*} \mathrm{p}<.01$

\section{Principal Leadership Score}

Cronbach's Alpha for the eight survey items is listed as .987 . Table 10 shows that Corrected Item-Total Correlation and Cronbach's Alpha if Item Deleted were used to gauge the internal consistency of the eight School Climate Survey items used in this 
study. Overall, these items have high internal consistency. Even if one of these items were deleted, it does not seem to have a meaningful effect. Essentially this means that teachers who tended to select Strongly Agree for one survey item also tended to select Strongly Agree for the others; similarly, teachers who selected Strongly Disagree for one survey item likely selected Strongly Disagree for the other survey items. Thus, knowing the response for one survey item would enable the researcher to predict with some accuracy the possible responses for the other seven School Climate Survey items.

Table 10

Reliability Analysis

\begin{tabular}{lcc}
\hline \multicolumn{1}{c}{ Survey Item } & $\begin{array}{c}\text { Corrected } \\
\text { Item-Total } \\
\text { Correlation }\end{array}$ & $\begin{array}{c}\text { Cronbach's } \\
\text { Alpha if } \\
\text { Item } \\
\text { Deleted }\end{array}$ \\
\hline 7. My principal is an effective administrator. & .947 & .985 \\
8. My principal represents the school in a positive manner. & .958 & .985 \\
9. My principal demonstrates good interpersonal skills. & .949 & .985 \\
10. My principal deals with conflict constructively. & .976 & .984 \\
11. My principal responds in a reasonable time to my concerns. & .907 & .987 \\
12. My principal treats me with respect. & .928 & .987 \\
13. My principal is receptive to constructive criticism. & .958 & .984 \\
14. My principal is supportive of teachers. & .973 & .984 \\
\hline
\end{tabular}

With the information conveyed in Table 10, it was determined that the eight School Climate Survey items essentially convey the same message. As a result of this determination, the researcher created a composite variable (Pallant, 2007) from the eight School Climate Survey items. Titled Principal Leadership Score, Table 11 provides descriptive statistics for the composite variable that was created. 
Table 11

Combined Principal Leadership Score

\begin{tabular}{lcccc}
\hline & & & & Standard \\
& Minimum & Maximum & Mean & Deviation \\
Principal Leadership Score & 2.74 & 4.99 & 4.28 & .40 \\
\hline
\end{tabular}

To give further insight, the Principal Leadership Score was studied by school grade. Table 12's data appears to be representative of the grade distribution found in Table 2. Interestingly, Table 12 makes it clear that there is not a statically significant difference between the mean Principal Leadership score of the " $\mathrm{A}$ " schools and the mean Principal Leadership score of the "F" schools.

\begin{tabular}{|c|c|c|c|c|}
\hline Grade & Median & Mean & $\begin{array}{l}\text { Standard } \\
\text { Deviation }\end{array}$ & $\mathrm{N}$ \\
\hline A & 4.44 & 4.39 & .34 & 195 \\
\hline B & 4.27 & 4.23 & .39 & 51 \\
\hline C & 4.08 & 4.11 & .45 & 57 \\
\hline D & 4.00 & 3.98 & .45 & 26 \\
\hline $\mathrm{F}$ & 4.33 & 4.31 & .27 & 9 \\
\hline Total & 4.33 & 4.28 & .40 & 338 \\
\hline
\end{tabular}

Similar to the correlations displayed in Table 9, the Principal Leadership Score was also evaluated for its correlation to points earned by schools. With regard to this study's research question, Table 12 shows that there was no statistically significant difference between the mean Principal Leadership Score for schools that earned an "A" and schools that earned an "F". 
Table 13

Pearson's r Correlation Between Principal Leadership Score and Points

Earned

\begin{tabular}{ll}
\hline & $\begin{array}{c}\text { Points } \\
\text { Earned }\end{array}$ \\
\hline Principal Leadership Score & $.310^{* *}$ \\
\hline Note. $n=338$ & \\
Note. ${ }^{* *} p<.01$ &
\end{tabular}

When interpreting the size of a correlation, it is common to square it (Weisstein, 2011). After Table 13's Pearson's $r$ correlation, .31, was squared, $r^{2}$ was found to be .09 . $r^{2}$ measures how much the variability in one variable can be explained by variation in another variable. In the case of this study, an $r^{2}$ of .09 means that approximately $9 \%$ of the variance in the points earned by schools in 2009 could be accounted for by how teachers in this study perceived the leadership of their principals. By considering the information presented in Table 12 as well as the information presented in Table 13, it can be determined that, regardless of a school's grade, the principal's leadership may account for $9 \%$ of a school's earned points.

Even though it was found that a moderate positive correlation exists between the composite variable created with instructional staff members' responses to survey items about their school's principal on the School Climate Survey and the number of points schools earn toward their school grades in Miami-Dade County Public Schools, it is important to remember that these results do not speak toward causation. In other words, these data do not mean that the type of administrator a principal is causes a school's earned points to increase. Rather, it means that a positive correlational relationship is likely to exist between Miami-Dade County Public School's School Climate Survey items related to principal leadership and points earned by schools, a derivative of school 
grades. This kind of insight is important because it supports the findings of researchers like Dow and Oakley (1992) Goddard, Sweetland and Hoy (2000), Hannum (1994), Hoy and Forsyth (1986), Hoy and Hannum (1997), Leithwood (1992) as well as Stewart (2008), who all found that there is a relationship between principal leadership and the effectiveness of their schools.

\section{Summary of Data Analysis}

All eight School Climate Survey items were analyzed and showed similar trends. It was found that survey item 12, My principal treats me with respect, had the highest mean percentage for Strongly Agree. Survey item 13, My principal is receptive to constructive criticism, had the lowest mean percentage for Strongly Agree. Individual survey items were intercorrelated and it was found that there was a strong correlation between survey items. The weakest intercorrelation between survey items was .88 and the strongest intercorrelation between survey items was .96. A composite variable, titled Principal Leadership Score, was created out of the eight survey items. With regard to this study's research question, there was no statistically significant difference between the Mean Principal Leadership Score of "A" schools and the Mean Principal Leadership Score of "F" schools (Table 12). Ultimately, it was found that principal leadership may account for 9\% of school's earned points regardless of the school's grade. 


\section{CHAPTER V}

\section{SUMMARY, IMPLICATIONS AND RECOMMENDATIONS}

This chapter includes a summary of the findings and implications supported by this study, as well as recommendations based upon these findings. This study examined the relationship between staff perceptions of principal leadership and school performance.

\section{Summary}

The relationship between principal leadership and school performance has been explored by educational researchers (Dow \& Oakley, 1992). A principal's leadership style, either positive or negative, influences the climate that impacts student performance (Pepper \& Thomas, 2002). For instance, Hoy (1972) found that schools with an open, healthy climate positively impact students.

The following research question and research hypothesis were analyzed: Does a statistically significant relationship exist between instructional staff members' responses to survey items about their school's principal on the School Climate Survey and the number of points schools earn towards their school grades in Miami-Dade County Public Schools? Hypothesis: A statistically significant relationship exists between instructional staff members' responses to survey items about their school's principals on the School Climate Survey and school grades in Miami-Dade County Public Schools.

To answer the research question, this study examined the relationship between instructional staff members' perceptions of principal leadership and school performance. 
Through the use of Florida Department of Education's school grades and Miami-Dade County Public Schools' School Climate Surveys, instructional staff members' responses to survey items about principal leadership were grouped by the number of points earned in a statewide FCAT performance evaluation process that was overseen by Florida's Department of Education for the 2008-2009 school year.

By focusing on relationships between variables, the research design of this study was ex-post-facto and, therefore, causation could not be determined (Newman \& Benz, 1998). The study took place in Miami-Dade County Public Schools, which employed approximately 21,000 teachers, and operated 415 schools, for the 2008-2009 school year. Due to the large sample size being used within this study, higher degrees of external validity were achievable.

After calculating points related to eight measures of achievement as well as two additional conditions, Florida's Department of Education assigned grades to schools for the 2008-2009 school year (Table 2). The total number of points earned by each school as well as school grades for the 2008-2009 school year were released to the public in June of 2009. Out of the 415 total schools operating in Miami-Dade County Public Schools for the 2008-2009 school year, Florida's Department of Education Website listed school grades for 367 of them (Florida School Grades, 2011). Of those 367 Miami-Dade County Public Schools identified as earning school grades on Florida's Department of Education website, 338 had School Climate Survey results posted by individual school for the 20082009 school year on MDCPS' Research Services website (Miami-Dade County Public Schools, 2009). 
Within the School Climate Survey for staff members, eight staff survey items were analyzed for this study. Those eight survey items are:

7. My principal is an effective administrator.

8. My principal represents the school in a positive manner.

9. My principal demonstrates good interpersonal skills.

10. My principal deals with conflict constructively.

11. My principal responds in a reasonable time to my concerns.

12. My principal treats me with respect.

13. My principal is receptive to constructive criticism.

14. My principal is supportive of teachers. (Appendix A).

Approximately 25,000 instructional staff members received invitations to respond to Miami-Dade County Public Schools' 2008-2009 School Climate Survey Staff Form. For that school year, the School Climate Survey Staff Form had a return rate of 75\% (Miami-Dade County Public Schools, 2009).

All data used for this study is public domain and can be found on-line. As a result of this, Miami-Dade County Public Schools' Research Services did not require the researcher to submit a Research Review Form for the use of Miami-Dade County Public Schools' School Climate Survey data (T. Chebbi, personal communication, August 30, 2011). The researcher gathered individual schools' averaged staff survey responses to survey items 7-14 for the 2008-2009 school year by going online to Miami-Dade County Public Schools' Research Services website and accessing individual schools' Staff Form reports (Appendix A). 
Quantitative data for this study was entered into MicroSoft Excel and then transferred into SPSS. Response categories within the School Climate Survey's 5-point Likert scale ranged from Strongly Agree to Strongly Disagree.

Pearson's correlation analysis was used to determine the relationship between schools' earned points and averaged survey responses (Healey, 2004). Survey items were found to have weak positive correlations, as well as moderate positive correlations, to schools' earned points (Table 9).

After determining that there were high intercorrelations between this study's independent variables, the School Climate Survey responses (Table 8), the researcher created a composite variable (Pallant, 2007). This composite variable, titled Principal Leadership Score, was analyzed for its correlation to points earned by schools. With this composite score it was concluded that principal leadership may contribute to $9 \%$ of a school's earned points regardless of the school's grade. Finally, with regard to the researcher's hypothesis, it was found that there was not a statistically significant difference between the mean Principal Leadership Score of the "A" schools and the mean Principal Leadership Score of the "F" schools (Table 12).

\section{Implications}

Hannum (1994) found that there is a strong positive correlation between schools with open climates and school performance. The fact that there was a moderate positive correlation between teachers' perceptions of principal leadership and school performance supports earlier research linking school climate and school performance (Benner et al., 2008; Dow \& Oakley, 1992; Hannum,1994; Hoy, 1972; Hoy \& Hannum, 1997; Koth et 
al., 2008; Liethwood \& Jantzi, 2000; Nettles \& Herrington, 2007; Stewart, 2007; Uline \& Tschannen-Moran, 2008; Witziers, et. al., 2003). Even so, there was very little difference between high-performing " $\mathrm{A}$ " schools and lower-performing "F" schools. As one can see from Table 12, the largest mean was 4.39 and the smallest mean was 3.98. Given the standard deviation, it appears that there is virtually very little meaningful difference between the mean ratings of the School Climate Survey responses and the grades of "A", "B", "C", "D" and "F" schools. The researcher feels that possible reasons for this lack of a meaningful difference should be articulated.

Research suggests that anonymous surveys with no identifying factors are more likely to produce honest responses than those identifying the respondent (Walonick, 2004). Furthermore, Walonick (2004) proposes that survey responses will inevitably become more distorted when subjects feel their identities may become known. Even though Miami-Dade County Public Schools' on-line School Climate Survey was supposed to be an anonymous survey, the on-line program prompted teachers to include biographical data before responding to survey items. For instance, teachers were asked to indicate the number of years they had taught, the subject area they taught, their gender, their ethnicity, etc. While some survey research suggests that adding a biographical section to surveys helps with data analysis (Knapp \& Mujtaba, 2009), in the case of Miami-Dade County Public Schools' School Climate Survey, it is possible that many teachers felt their anonymity was threatened by the survey's request for biographical data. Respondents may have feared that their principals had access to their anonymous survey responses and, as a result of their biographical data, principals could determine 
which teachers completed the survey as well as how they responded. With this in mind, it is possible that teachers' fears contributed to them rating their principals differently, or more positively, than they would have if they had felt their anonymity was guaranteed (Edwards, Thomas, Rosenfeld, \& Booth-Kewley, 1997). Given this, the researcher believes it would be beneficial for Miami-Dade County Public Schools' Research Services department to remove all prompts requesting biographical data of respondents. By removing prompts for personal information, respondents may be more likely to answer survey items openly and honestly.

As noted by Blasé and Blasé (2002) and Hoyle (1986), nearly all teachers fear incurring the wrath of their principals. That being said, regardless of whether teachers participating in Miami-Dade County Public Schools' School Climate Survey worked in an "A" school or an "F" school, it is likely that participants in all of the schools were worried about workplace abuse or principal retaliation if they were anything less than positive in their survey responses. The similar fear that many teachers share of workplace mistreatment (Blasé and Blasé, 2002) and the dark side of their school's organizational life (Hoyle, 1986) could further explain why survey results from dissimilar schools were so comparable.

Stewart (2008) found that principal leadership indirectly impacts the performance of teachers under their leadership as well as the climate and culture of their schools. Many times, researchers' focus on the direct effect of principal behavior on student learning has been replaced by a focus on the overall influence principals' behavior has on student achievement (Nettles \& Herrington, 2007; Witziers, Bozkers, \& Kruger, 2003). 
Through the use of eight survey items within this study, the researcher attempted to focus on specific principal leadership skills. It is important to consider the survey items that were used were modified from an original climate index and the original standardization process of that scale was based upon a different subset of items. However, the data for this survey on the eight items selected indicated a very acceptable Cronbach's Alpha of greater than .9.

With regard to the eight survey items used for this study from Miami-Dade County Public Schools' School Climate Survey, it was found that teachers' ratings of their principals did not typically deviate from item to item. The fact that responses for each item were so similar may have many implications. Even though Miami-Dade County Public School found these eight survey items to be relevant to competent leadership, the County's 2001 Research Brief discussing the eight survey items used for this study did not provide information regarding validity and reliability estimates. Reeves (2005) notes that assessments of educational leaders may measure responses accurately, but that those responses cannot be used for performance assessment. Furthermore, Goldring, Cravens, Murphy, Porter, Elliott, \& Carson (2009) found that school districts often use peculiar and unreliable measures for principal performance assessment.

According to Edwards et al. (1997), organizational climate surveys have increased in popularity, which could impact how seriously respondents feel about surveys they are asked to complete. Even though Miami-Dade County Public Schools' Research Brief (2001) found a, "moderate general linear relationship, with lower school grades being associated with lower principal ratings by teachers on the school climate survey" (p. 5), 
the researcher believes that the language used for survey items was not precise enough, meaning that the survey items did not adequately distinguish themselves as separate and unique. This belief by the researcher may be supported by the fact that Miami-Dade County Public Schools' Research Brief (2001) found the eight survey items used in this study to be, "highly correlated" (p. 1), essentially creating an effectiveness factor that this study referred to as the Principal Leadership Score.

Considering the fact that Edward et al. assert surveys of this nature are becoming more of a common practice, it is possible that, once respondents responded to the first survey item about their principals, they automatically answered the remaining survey items similarly, not necessarily taking the survey items as seriously as they might have if the survey items were distinct, and if the survey was constructed differently. For instance, Bickman and Rog (2009) found that the way in which respondents are asked to answer survey questions impacts their response. To help deter participants from responding to survey items without giving each item due consideration, the researcher recommends breaking the survey's singular principal section into subsections, thereby drawing the attention of respondents to the fact that they are entering new response categories with regard to their principal's leadership.

Finally, Lashway (2003) found that asking different constituents to rate principal performance is a growing trend. With that in mind, the researcher believes there is positive value in asking more than instructional staff members to evaluate principal performance. For instance, custodians, security monitors and clerical employees may have unique perspectives related to their principals that could help researchers better understand principal performance. 


\section{Recommendations}

The following recommendations are made based upon the findings and conclusions of this study, using data from the 2009 FCAT, and Miami-Dade County Public Schools' 2009 School Climate Survey results from instructional staff members.

Due to the fact that the leadership of the principal affects, either positively or negatively, the learning and working environment of students and teachers (Pepper \& Thomas, 2002), it is recommended that principals use the eight School Climate Survey items examined within this study as guides. Through focusing on these survey items, principals may be propelled to self-identify their leadership strengths as well as their leadership weaknesses. Principals working toward improving the leadership skills identified on the Miami-Dade County Public Schools' School Climate Survey would be improving their transformational leadership skills, which might improve their school's climate, and could, in turn, possibly improve the performance of their schools (Blasé and Blasé, 2000; Hackman \& Johnson, 2000; Horan, 1999; Kouzes \& Posner, 2002; Leithwood, 1992; Sergiovanni, 1996).

Due to national and state demands, mandates for student achievement are likely to continue. As a result, improving the level of school performance in the United States has become a national priority (Marzano, 2000). To help with this, data from this study should be shared with school principals. Furthermore, this study's findings could aid professional organizations that are exploring the impact of principal leadership on school performance. Along those same lines, this study could be used to help advance the body

of research related to principal leadership, specifically behaviors that will improve school 
climate, which has been linked with school performance (Benner et al., 2008; Hoy \& Hannum, 1997; Koth, Bradshaw, \& Leaf, 2008; Stewart, 2007; Uline \& TschannenMoran, 2008).

Considering principal leadership may account for 9\% of a school's earned points, a possible need may exist for the inclusion of some version of these eight School Climate Survey items in the training of Miami-Dade County Public School's principals. Mentor programs geared toward developing these skills could increase the presence of transformational leadership in schools and may positively impact student performance on the FCAT.

Miami-Dade County Public Schools' School Climate Survey is a quantitative measurement tool. As a follow up to this study, a qualitative study could be conducted. For instance, interviews could be conducted or open-ended questionnaires could be sent to principals as well as instructional staff members (Edwards et al., 1997). By giving respondents greater latitude when responding to leadership assessment prompts, surveys of this nature may offer new insight into the impact principal leadership may have on school grades. A qualitative study may provide researchers with the opportunity to use new variables (Knapp \& Mujtaba, 2009), such as asking respondents about the number of principals they have worked with or exploring the impact assistant principals have on principal performance. Furthermore, a qualitative study could allow researchers to focus on the process of how principals develop the skills their teachers evaluate them on through tools such as Miami-Dade County Public Schools' School Climate Survey (Edwards et al., 1997). 
This study could be replicated with new factors for consideration, such as principals' years of experience. Due to the fact that there was very little meaningful difference between the mean ratings of principals' School Climate Survey evaluations and the grades of schools, new factors could provide further understanding of differences that were not explored within this study and could then be used for intervention in the future.

Nearly all research related to the topic of principal leadership and its impact on school performance indicates leadership matters. Even so, this study found that principal leadership between high-performing schools and low-performing schools was inconsequential. The contrast between an overwhelming body of research and this study's findings points toward a need for further investigation. 


\section{REFERENCES}

Annual Climate Survey. (2009). Annual climate survey. Retrieved from Miami-Dade County Public Schools Research Services Online:

http://drs.dadeschools.net/SchoolClimateSurvey/SCS.asp

Araki, C. T. (1982). Leadership study in Hawaii - How characteristics of principals affect schools. NASSP Bulletin 66, 88-96.

Benner, A. D., Graham, S., \& Mistry, R. S. (2008). Discerning direct and mediated effects of ecological structures and processes on adolescents' educational outcomes. Developmental Psychology, 44(3), 840-854.

Bickman, L. \& Rog, D. (2009). The handbook of applied social research methods. Los Angeles, CA: Sage Publications, Inc.

Blasé, J., \& Blasé, J. (2000). Effective instructional leadership: Teachers' perspectives on how principals promote teaching and learning in schools. Journal of Educational Administration, 38, 130-141.

Blasé, J., \& Blasé, J. (2002). Breaking the silence: Overcoming the problem of principal mistreatment of teachers. Thousand Oaks, CA: Corwin.

Brofenbrenner, U. (1979). The ecology of human development: Experiments by nature and design. Cambridge, MA: Harvard University Press.

Carbonaro, W. (2005). Tracking students' efforts, and academic achievement. Sociology of Education, 78, 27-49.

Cawelti, G. (1984). Behavior patterns of effective principals. Educational Leadership, 41(5), 3. Retrieved from Academic Search Premier database.

Cronbach, L. (1951). Coefficient alpha and the internal structure of tests. Psychometrica, $16,527-530$.

Cunningham, G. K. (2003). Can education schools be saved? American Enterprise Institute for Public Policy Research. Retrieved from http://www.aei.org/favicon.ico

Day,C. (2000). Beyond transformational leadership. Educational Leadership, 57(7), 5659.

Deal, T., \& Peterson, I. (1990). The principal role in shaping school culture. San Francisco, CA: Jossey-Bass. 
Dow, I. I., \& Oakley, W. F. (1992). School effectiveness and leadership. Alberta Journal of Educational Research, 38(1), 14.

DuFour, R., \& Berkey, T. (1995). The principal as staff developer. Journal of Staff Development, 16(4), 2-6.

Edwards, J. E., Thomas, M. D., Rosenfeld, P., \& Booth-Kewley, S. (1997). How to conduct organizational surveys? Thousand Oaks, CA: Sage Publications, Inc.

Florida Department of Education. (2011). Florida School Grades. Retrieved from Florida Department of Education's School Accountability Reports http://schoolgrades.fldoe.org/

Gall, M., Gall, J., \& Borg, W. (2003). Educational research: An introduction. Boston, MA: Allyn and Bacon.

Goldring, E., Cravens, X., Murphy, J., Porter, A., Elliott, S., \& Carson, B. (2009). The evaluation of principals: What and how do states and urban districts assess leadership? The Elementary School Journal, 110(1), 19-39.

Hackman, M. Z., \& Johnson, C. E. (2000). Leadership: The communication perspective. Prospect Heights, IL: Waveland Press.

Halpin, A. W., \& Croft, D. B. (1963). The organizational climate of schools. Chicago, IL: Midwest Administration Center.

Hannum, J. (1994). The organizational climate of middle schools, teacher efficacy, and student achievement (Doctoral dissertation). Retrieved from SAGE Journals Online: http://eaq.sagepub.com/cgi/reprint/33/3/290

Healey, Joseph F. (2004). Statistics: A tool for social research $\left(7^{\text {th }}\right.$ ed.). Belmont, CA: Wadsworth Publishing

Heck, R. H., Larsen, T. J., \& Marcoulides, G. A., (1990). Instructional leadership and school achievement: Validation of a causal model. Educational Administration Quarterly, 26(2), 94-125.

Heifetz, R. A. (1994). Leadership without easy answers. Cambridge, MA: Harvard University Press.

Hinkle, D.E., Wiersma, W., \& Jurs, S.G. (2003). Applied statistics for the behavioral sciences $\left(5^{\text {th }} \mathrm{ed}\right)$. New York: Houghton Mifflin.

History of School Grades. (2009). History of school grades. Retrieved from Florida Department of Education. Online: http://schoolgrades.fldoe.org/pdf/0809/SchoolGrades2009_11.pdf 
Horan, J. (1999). Leadership. Orana, 35(2), 19-25. Retrieved from Academic Search Premier database.

Houchard, M. A. (2005). Principal leadership, teacher morale, and student achievement in seven schools in Mitchell County (Doctoral dissertation). Retrieved from ProQuest website: http://proquest.umi.com/pqdink?Ver=1\&Exp=03-01$2015 \& \mathrm{FMT}=7 \& \mathrm{DID}=1014317191 \& \mathrm{RQT}=309 \&$ attempt $=1 \& \mathrm{cfc}=1$

Hoy, W. K. (1972). Dimensions of student alienation and characteristics of public schools. Interchange, 3, 38-51.

Hoy, W. K., \& Clover, S. (1986). Elementary school climate: A revision of the OCDQ. Educational Administration Quarterly, 22, 93-100.

Hoy, W. K., \& Forsyth, P. B. (1986). Effective supervision, theory into practice. New York, NY: Random House.

Hoy, W. K., \& Hannum, J. W. (1997). Middle school climate: An empirical assessment of organizational health and student achievement. Educational Administration Quarterly, 33(3), 290-311.

Hoy, W., Hannum, J., \& Tschannen-Moran, M. (1998). Organizational climate and student achievement: A parsimonious view and longitudinal view. Journal of School Leadership, 8, 336-359.

Hoy, W. K., Hoffman, W. J., Sabo, D., \& Bliss, J. (1996). The organizational climate of middle schools: The development and test of the OCDQ-RM. Journal of Educational Administration, 34, 41-71.

Hoy, W. K., \& Miskel, C.G. (1991). Educational administration: Theory, research, and practice. NJ: McGraw-Hill.

Hoyle, E. (1986). The politics of school management. London, England: Hodder and Straughton.

Hunter-Boykin, H. S., Evans, V. (1995). The relationship between high school principals' leadership and teachers' morale. Journal of Instructional Psychology, 22(2), 152162. Retrieved from Academic Search Premier database.

Kerlinger, F. N., \& Lee, H. B. (2000). Foundations of behavioral research (4th ed.). Fort Worth, TX: Harcourt College.

Knapp, P. R. and Mujtaba, B. G. (2009). Designing, administering, and utilizing an employee attitude survey. Journal of Behavioral Studies in Business, 2(1), 1-14. 
Koth, C. W., Bradshaw, C. P., \& Leaf, P. J. (2008). A multilevel study of predictors of student perceptions of school climate: The effect of classroom level factors. Journal of Educational Psychology, 100(1), 96-104.

Kouzes, J. M., \& Posner, B. Z. (2002). The leadership challenge (3rd ed.). San Francisco, CA: Jossey-Bass.

Lashway, L. (2003). Improving principal evaluation. ERIC Digest. Eugene, OR: ERIC Clearinghouse on Educational Management.

Leithwood, K. (1992). The move towards transformational leadership. Educational Leadership, 49(5), 8-12.

Leithwood, K., \& Jantzi, D. (2000). The effects of transformation leadership on student engagement with school. Journal of Educational Administration, 38, 112-129.

Leitner, D. (1994). Do principals affect student outcomes: An organizational perspective. School Effectiveness and School Improvement, 5, 219-238.

Likert, R. (1961). New patterns of management. New York, NY: McGraw-Hill.

Marzano, R. J. (2000). Transforming classroom grading. Alexandria, VA: Association for Supervision and Curriculum Development.

Marzano, R. J., Waters, T., \& McNulty, B. A. (2005). School leadership that works. Alexandria, VA: Association for Supervision and Curriculum Development.

McNeil, K., Newman, I., \& Kelly F. J. (1996).Testing research hypotheses with the general linear model. Carbondale, IL: Southern Illinois University Press.

Miami-Dade County Public Schools. (2009). School Climate Surveys district results for 2008-2009. Retrieved from Miami-Dade County Public Schools Research Services http://drs.dadeschools.net/SchoolClimateSurvey/200809/District\%20Results\%20for\%202008-09.pdf

Nettles, S. M., \& Herrington, C. (2007). Revisiting the importance of the direct effects of school leadership on student achievement: The implications for school improvement policy. Peabody Journal of Education, 82(4), 724-736.

Newman, I., \& Benz, C. R. (1998). Qualitative-quantitative research methodology: Exploring the interactive continuum. Carbondale, Illinois: Southern Illinois University Press.

Newman, I., Benz, C. R., Weis, D., \& McNeil, K. (1997). Theses and dissertations: A guide to writing in the social and physical sciences. Maryland, MA: University Press of America. 
Newman, I., Newman, C., Brown, R., \& McNeely, S. (2006). Conceptual statistics for beginners (3rd ed.). Lanham, MD: University Press of America.

Norton, S. M. (1999). The work of the school principal in the area of human resources administration in Arizona. National Association of Secondary School Principals, 83 (603), 108-113.

Pace, C. R., \& Stern, G. C. (1958). An approach to measure the psychological characteristics of college environments. Journal of Educational Psychology, 49, 269-277.

Pallant, J. (2007). SPSS survival manual (3rd ed.). London, England: Open University Press.

Pepper, K., \& Thomas, L. H. (2002). Making a change: The effects of the leadership role on schools climate. Learning Environments Research, 5, 155-166.

Rea, P.J., McLaughlin, V. L., \& Walther-Thomas, C.J. (2002). A comparison of outcomes for middle school students with learning disabilities in inclusive and pullout programs. Exceptional Children, 68, 203-222.

Reeves, D.B. (2005). Assessing educational leaders: Evaluating performance for improved individual and organizational results. Thousand Oaks, CA: Corwin.

Research Brief. (2002). Teachers rate the principals: Staff responses to the School Climate Survey 2001. Miami, FL: Miami-Dade County Public Schools, office of Evaluation and Research.

Romanik, D. \& Froman, T. (1992). Results from the 1991-1992 administration of the school report card survey. Miami, FL: Dade County Public Schools, office of Educational Accountability.

Rousmaniere, K. (2007). Go to the principal's office: Toward a social principal in North America. History of Education Quarterly, 47(1), 1-22. Retrieved from Education Research Complete database.

Saphier, J., King, M., \& D’Auria, J. (2006). 3 Strands form strong school leadership. Journal of Staff Development, 27(2), 51-59.

Sergiovanni, T. J. (1996). Leadership for the schoolhouse. San Francisco, CA: JosseyBass.

Smith, E. (2009). 2009 Guide to calculating school grades. Retrieved from Florida Department of Education Online http://schoolgrades.fldoe.org/pdf/0809/2009SchoolGradesTAP.pdf 
Statewide Assessment Calendar. (2009). Statewide assessment calendar. Retrieved from Florida Department of Education Online http://www.fldoe.org/asp/k12memo/pdf/2009StatewideAssessmentCalendarSprea dsheet. pdf.

Statistical Highlights. (2009). Statistical Highlights 2008-2009. Retrieved from MiamiDade County Public Schools Research Services Online http://drs.dadeschools.net/StatisticalHighlights/SH08-09.pdf

Stern, G. G. (1970). People in context: Measuring person-environment in education and industry. New York, NY: John Wiley.

Stewart, E. B. (2007). Individual and school structural effects on African American high school students' academic achievement. The High School Journal, 91(2), 1634.

Stewart, E. B. (2008). School structural characteristics, student effort, peer associations, and parental involvement: The influence of school- and individual-level factors on academic achievement. Education and Urban Society, 40(2), 179-202.

Sufka, K. J., \& George, M. D. (2000). Setting clear and mutual expectations. Liberal Education, 86(1), 48-53.

Uline, C., Tschannen-Moran, M. (2008). The walls speak: The interplay of quality facilities, school climate, and student achievement. Journal of Educational Administration, 46(1), 55-73.

Usdan, M., McCloud, B., \& Podmostko, M. (2000). Leadership for student learning: Reinventing the principalship. Washington, DC: Institute of Educational Leadership.

Walonick, D. (2004). Survival statistics. Bloomington, IN: StatPac.

Weisstein, E. (2011). Correlation coefficient. Retrieved from MathWorld--A Wolfram Web Resource http://mathworld.wolfram.com/CorrelationCoefficient.html

Wentworth, M. (1990). Developing staff morale. The Practitioner, 16(4), 1-8.

Willower, D. J., Eidell, T. L., \& Hoy, W. K. (1986). The school and principal control ideology. New York, NY: Random House.

Wilson, D. (2004). The interface of school climate and connectedness and relationships with aggression and victimization. Journal of School Health, 74, 293-299.

Witziers, B., Bosker, R. J., \& Kruger, M. L. (2003). Educational leadership and student achievement: The elusive search for an association. Educational Administration Quarterly, 39, 398-425. 
APPENDICES

Appendix A

School Climate Survey

District Summary of Staff Responses 2008-2009 


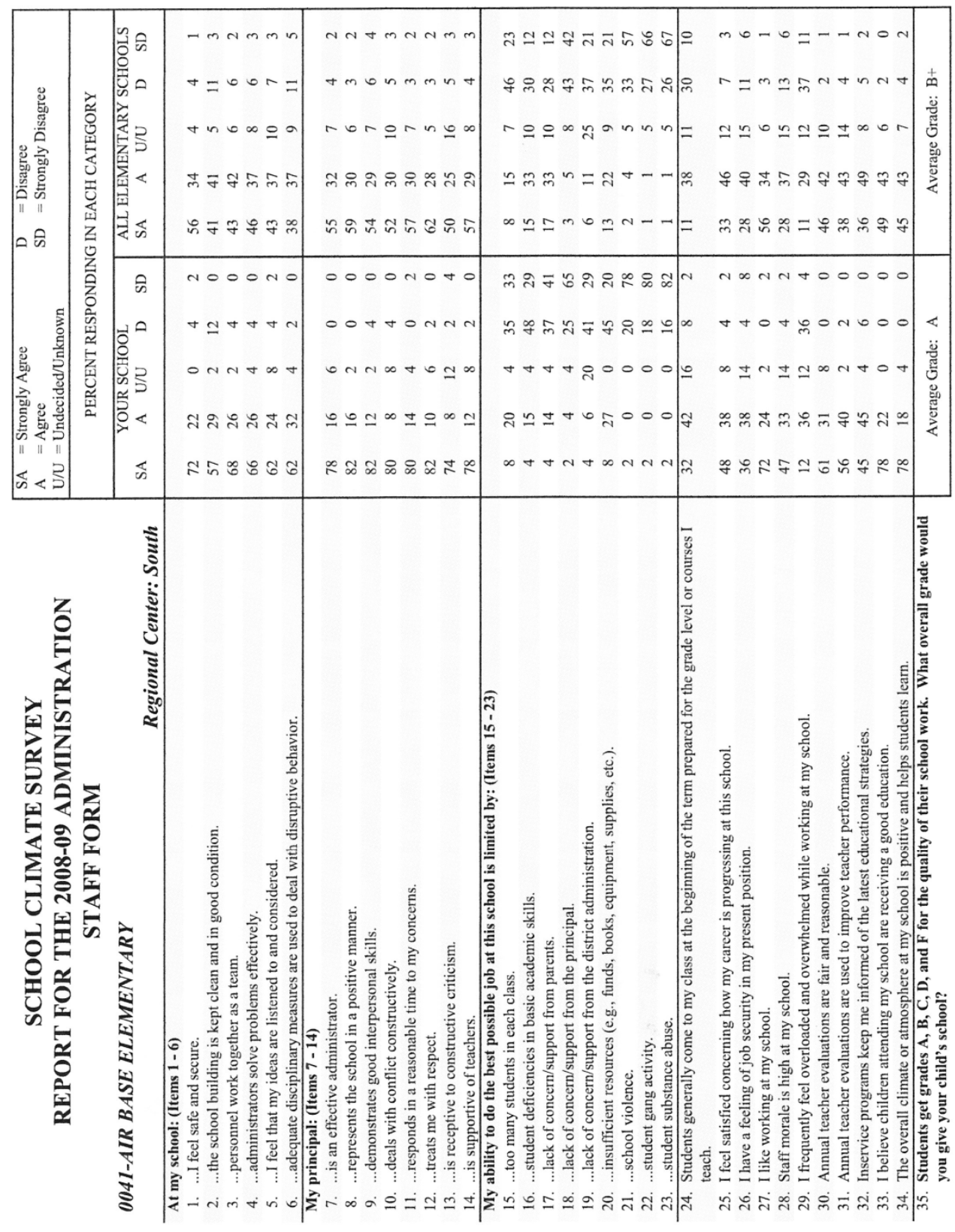


Appendix B

School Climate Survey Staff Form Envelope 


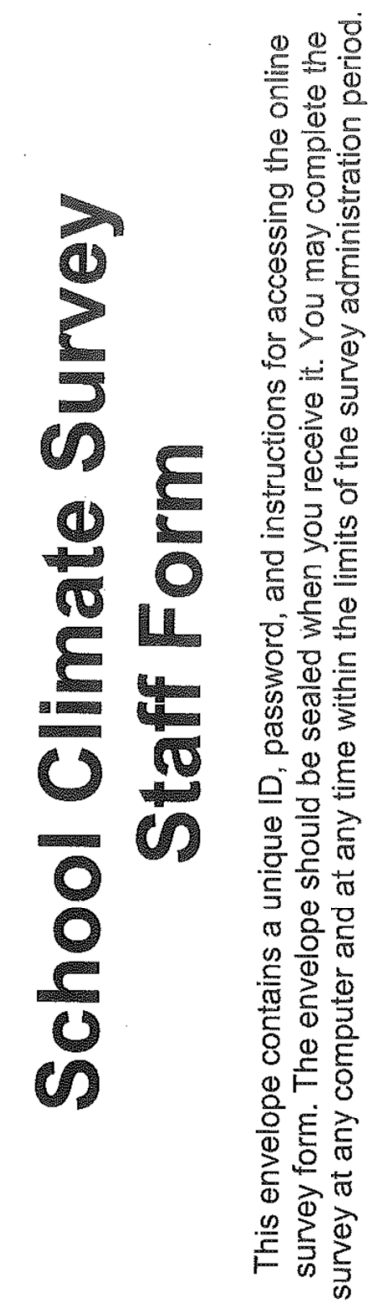


Appendix C

School Climate Survey for Instructional Staff Instructions 


\section{SCHOOL CLIMATE SURVEY \\ FOR INSTRUCTIONAL STAFF}

\section{INSTRUCTIONS}

The School climate Survey for administrative and instructional staff is conducted via the Internet. You may access the survey by going to the M-DCPS Research Services website (http://drs.dadeschools.net). There you will see a button/link taking you to the survey site. If another person has used the same computer to access the survey, it is strongly suggested you clean the cache before you attempt to complete the survey. You will need an ID number and a password to access the form. These numbers are given immediately below.

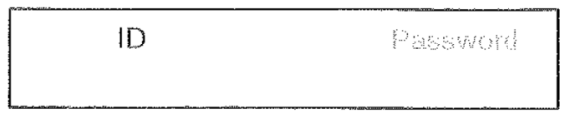

This ID number is known only to the person who has chosen this envelope, and must be used to gain access to the survey form. It can be used only once. After the respondent has used the ID number to access the form, it will be deleted from the master list on the server, which is maintained by an Internet service company, Infopoll. The purpose of the ID number is solely to control access to the survey form.

The survey form will be available on-line for one month. You may access the survey site at your convenience and from any computer with Internet access, at any time during this period. Please have your ID number and password handy, and know the location number of your school. SCHOOLS ARE LISTED BY LOCATION NUMBER. Respondents at schools with the same or similar name as schools at other organizational levels should take particular care to choose the correct school from the drop down list.

Infopoll will be providing us with a running count of the number of participants answering the survey, broken down by school location number, and we will post this information by school on the Research Services website (http://drs.dadeschools.net) at regular intervals throughout the survey period. We invite you to visit our site and watch your school's progress.

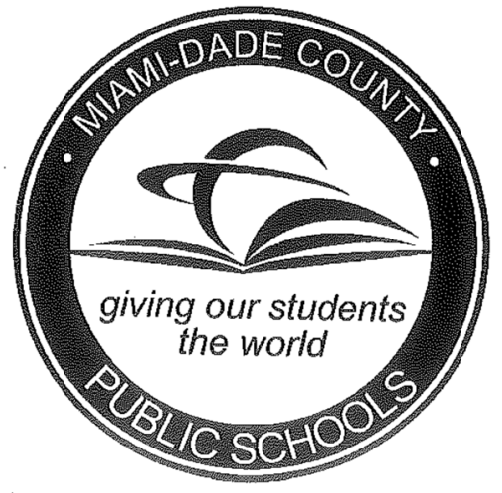




\section{Appendix D}

Table 14

Distribution of Mean Percentage of Teachers and Standard Deviations for Each Survey Item 
Table 14

Distribution of Mean Percentage of Teachers and Standard Deviations for Each Survey Item

\begin{tabular}{|c|c|c|c|c|c|}
\hline Survey Item & $\begin{array}{l}\text { Strongly } \\
\text { Agree }\end{array}$ & Agree & $\begin{array}{l}\text { Undecided/ } \\
\text { Unknown }\end{array}$ & Disagree & $\begin{array}{l}\text { Strongly } \\
\text { Disagree }\end{array}$ \\
\hline 7. My principal is an effective administrator. & $\begin{array}{c}52.8 \\
(20.8)\end{array}$ & $\begin{array}{c}32.6 \\
(12.7)\end{array}$ & $\begin{array}{c}7.7 \\
(6.8)\end{array}$ & $\begin{array}{c}4.5 \\
(5.3)\end{array}$ & $\begin{array}{c}2.6 \\
(4.4)\end{array}$ \\
\hline $\begin{array}{l}\text { 8. My principal represents the school in a } \\
\text { positive manner. }\end{array}$ & $\begin{array}{c}58.6 \\
(19.9)\end{array}$ & $\begin{array}{c}31.4 \\
(13.2)\end{array}$ & $\begin{array}{c}5.7 \\
(5.7)\end{array}$ & $\begin{array}{c}2.4 \\
(3.8)\end{array}$ & $\begin{array}{l}2.0 \\
(3.7)\end{array}$ \\
\hline $\begin{array}{l}\text { 9. My principal demonstrates good } \\
\text { interpersonal skills. }\end{array}$ & $\begin{array}{c}52.7 \\
(20.8)\end{array}$ & $\begin{array}{c}30.3 \\
(11.8)\end{array}$ & $\begin{array}{l}7.1 \\
(5.7)\end{array}$ & $\begin{array}{c}6.3 \\
(6.5)\end{array}$ & $\begin{array}{l}3.6 \\
(5.4)\end{array}$ \\
\hline $\begin{array}{l}\text { 10. My principal deals with conflict } \\
\text { constructively. }\end{array}$ & $\begin{array}{c}50.1 \\
(20.4)\end{array}$ & $\begin{array}{c}30.3 \\
(11.4)\end{array}$ & $\begin{array}{l}10.9 \\
(7.9)\end{array}$ & $\begin{array}{c}5.6 \\
(6.0)\end{array}$ & $\begin{array}{l}3.1 \\
(4.7)\end{array}$ \\
\hline $\begin{array}{l}\text { 11. My principal responds in a reasonable time } \\
\text { to my concerns. }\end{array}$ & $\begin{array}{c}54.9 \\
(19.7)\end{array}$ & $\begin{array}{c}31.2 \\
(12.4)\end{array}$ & $\begin{array}{l}7.9 \\
(6.5)\end{array}$ & $\begin{array}{l}3.6 \\
(4.1)\end{array}$ & $\begin{array}{c}2.4 \\
(3.7)\end{array}$ \\
\hline 12. My principal treats me with respect. & $\begin{array}{c}61.7 \\
(18.0)\end{array}$ & $\begin{array}{c}28.7 \\
(12.5)\end{array}$ & $\begin{array}{c}4.6 \\
(4.5)\end{array}$ & $\begin{array}{l}2.7 \\
(3.3)\end{array}$ & $\begin{array}{l}2.3 \\
(3.6)\end{array}$ \\
\hline $\begin{array}{l}\text { 13. My principal is receptive to constructive } \\
\text { criticism. }\end{array}$ & $\begin{array}{c}47.7 \\
(19.5)\end{array}$ & $\begin{array}{c}25.4 \\
(10.3)\end{array}$ & $\begin{array}{l}17.9 \\
(9.9)\end{array}$ & $\begin{array}{c}5.5 \\
(5.2)\end{array}$ & $\begin{array}{c}3.6 \\
(4.7)\end{array}$ \\
\hline 14. My principal is supportive of teachers. & $\begin{array}{c}55.1 \\
(20.5)\end{array}$ & $\begin{array}{c}29.4 \\
(12.4)\end{array}$ & $\begin{array}{c}8.5 \\
(6.6)\end{array}$ & $\begin{array}{c}4.2 \\
(4.8)\end{array}$ & $\begin{array}{c}2.8 \\
(4.4)\end{array}$ \\
\hline
\end{tabular}

Note. $n=338$.

Note. Standard deviation listed in ( )'s. 
VITA

\section{ANDREA FLOYD}

June 30, 1978

2001

2002

2001- Present

2005-2009

2006- Present

2007- Present

2009- Present
Born, Homestead, Florida

B.S., English Education Florida State University

Tallahassee, Florida

M.S., English for Speakers of Other Languages University of Miami

Miami, Florida

Teacher

Southwood Middle School

Palmetto Bay, Florida

Team Leader

Southwood Middle School

Palmetto Bay, Florida

Adjunct Instructor

Miami-Dade County Public Schools

Miami, Florida

Designated Building Steward

United Teachers of Dade

Miami, Florida

Co-Founder, Bookbusters

Palmetto Bay Public Library

Palmetto Bay, Florida 